\title{
Carbon capture and utilization for Sodium Bicarbonate production assisted by solar thermal power
}

\author{
D. Bonaventura ${ }^{1,2}$, R. Chacartegui*1, J. M. Valverde' ${ }^{1}$, J. A. Becerra ${ }^{1}$, V. Verda ${ }^{* 2}$
}

1 University of Seville, Spain.

${ }^{2}$ Politecnico di Torino, Italy.

\begin{abstract}
In this paper, a novel carbon capture and utilization process is proposed. It is based on using a fraction of the captured carbon dioxide to produce sodium bicarbonate $\left(\mathrm{NaHCO}_{3}\right)$, a widely used product in the chemical and food industries. The process couples the Dry Carbonate process for $\mathrm{CO}_{2}$ capture with $\mathrm{NaHCO}_{3}$ production. Raw material is trona or sodium sesquicarbonate dehydrate $\left(\mathrm{Na}_{2} \mathrm{CO}_{3} \cdot \mathrm{NaHCO}_{3} \cdot 2 \mathrm{H}_{2} \mathrm{O}\right)$ which is a relatively abundant mineral composed by approximately $46 \%$ sodium carbonate $\left(\mathrm{Na}_{2} \mathrm{CO}_{3}\right)$ and $35 \%$ sodium bicarbonate $\left(\mathrm{NaHCO}_{3}\right)$ by weight. In the process trona is firstly converted into $\mathrm{Na}_{2} \mathrm{CO}_{3}$ in a fluidized bed reactor operated at $180-200^{\circ} \mathrm{C}$ and 1 bar. Heat required in the fluidized bed reactor for decomposing trona can be supplied by renewable sources such as low/medium temperature solar energy or biomass. A fraction of the $\mathrm{Na}_{2} \mathrm{CO}_{3}$ generated is recirculated for $\mathrm{CO}_{2}$ capture by means of the dry carbonate process. The rest is converted to $\mathrm{NaHCO}_{3}$ in a carbonating tower through the reaction with $\mathrm{CO}_{2}$ and $\mathrm{H}_{2} \mathrm{O}$. After separation of $\mathrm{NaHCO}_{3}$ and other salts from water, $\mathrm{NaHCO}_{3}$ is suitable for direct sale. The use of renewable sources for the energy required at the sorbent regenerator and trona decomposition yields a near-zero $\mathrm{CO}_{2}$ emissions global system. As case of study, $\mathrm{CO}_{2}$ capture coupled to $\mathrm{NaHCO}_{3}$ production has been analysed for a $15 \mathrm{MW}_{\mathrm{el}}$ coal fired power plant. Heat required in the carbon capture process penalizes the global system efficiency by a $10.2 \%$, which is reduced just to the electricity parasitic consumption for solids transport and $\mathrm{CO}_{2}$ compression $(\sim 3 \%)$ if renewable energy sources are integrated. From an economic perspective, the penalty in electricity consumption is fully compensated by the new byproduct sales. Taking into account the reduction of electricity sales and current prices of trona and $\mathrm{NaHCO}_{3}$ a return of investment is obtained in the range between 3 and 8.7 years with an internal rate of return over $12 \%$. These values improve the current forecast of any other carbon capture and storage process up to date, which suggests a high interest of the proposed conceptual integrations for regions where trona is widely available.
\end{abstract}

\section{Keywords:}

$\mathrm{CO}_{2}$ capture, Coal fired power plant, CCS, CCU, Dry carbonate process, Trona, Sodium bicarbonate. 


\section{Introduction}

2

A complete replacement of fossil fuels by renewable energies is not feasible in the short-term. Thus,

fossil fuel power plants should be urgently retrofitted with $\mathrm{CO}_{2}$ capture and sequestration (CCS) processes as a necessary measure to limit global warming below $2^{\circ} \mathrm{C}$ [1]. CCS would allow continuing the use of fossil fuel until a deeper penetration of renewable energy sources into the grid is attained in an orderly fashion. $\mathrm{CO}_{2}$ capture and utilization (CCU) for commercial purposes would help mitigating capture costs that mainly hinder the commercial deployment of state of the art $\mathrm{CO}_{2}$ capture technologies. Current anthropogenic $\mathrm{CO}_{2}$ emissions (around $35 \mathrm{Gt} / \mathrm{y}$ ) largely exceed the amount of $\mathrm{CO}_{2}$ used in chemical processes ( $\left.200 \mathrm{Mt} / \mathrm{y}\right)$. However, promoting $\mathrm{CO}_{2}$ utilization routes for the production of valuable chemicals could be a starting point to promote the deployment of $\mathrm{CO}_{2}$ capture technologies [2]. According to International Energy Agency (IEA) projections, the CCS share of cumulative emissions reduction to achieve the $2^{\circ} \mathrm{C}$ target would require about 3500 large-scale CCS projects in operation by 2050 . Only about 15 large-scale CCS commercial projects are in operation to this date of which Boundary Dam in Canada is the only coal fired power plant applying CCS in the power sector. Yet, it is estimated that abandoning CCS in the power sector would increase the investment required over $40 \%$ in the $2^{\circ} \mathrm{C}$ scenario [3]. Moreover, post-combustion capture technologies have the greatest potential for reduction of $\mathrm{CO}_{2}$ emissions in the short term because they can be retrofitted to existing fossil fuel power plants and are also applicable to other industrial processes.

Up to date the only post-combustion capture technology commercially available at the necessary large-scale of coal fired power plants is based on chemical absorption by amines dissolved in water. In this post-combustion capture system, the exhaust gases stream from the power plant is passed through an absorber column where it comes into contact with the liquid amine flowing downwards, which allows $\mathrm{CO}_{2}$ to be chemically absorbed by the amine. The $\mathrm{CO}_{2}$ rich amine solvent is then pumped to a regenerator, where heat is supplied to reverse the chemical reaction and release relatively pure $\mathrm{CO}_{2}$ for its compression, transport and storage while the $\mathrm{CO}_{2}$ lean liquid amine is pumped back into the absorber to be reused [4]. Although temperatures for $\mathrm{CO}_{2}$ desorption are not high $\left(\sim 130^{\circ} \mathrm{C}\right)$ sorbent regeneration in this process requires a relatively high amount of energy to heat the large volume of water where amines are dissolved. Thus, the energy required per ton of $\mathrm{CO}_{2}$ captured is about $3.3 \mathrm{GJ} /$ ton $_{\mathrm{CO} 2}$ for an advanced monoethanolamines (MEA) system whereas $3.9 \mathrm{GJ} /$ ton $_{\mathrm{CO} 2}$ are required for a typical aqueous MEA system [5]. On the other hand, post-combustion capture by MEA suffers from other serious issues related to toxicity, corrosion and degradation [6]. Furthermore, amines have a relatively high cost $(>1000 € /$ ton), which is a major problem taking into account the large scale of commercial CCS applications [1,7].

Thus, there is a need to develop novel post-combustion capture processes using cheap, widely available and non-toxic materials at reduced cost and energy penalty. In this line, novel amine-based solid sorbents based on direct steam stripping desorption have shown an improved performance [8]. In ref. [9] an organic solvent was added to a $\mathrm{CO}_{2}$ rich, aqueous ammonia/ $\mathrm{CO}_{2}$ solution under room temperature and pressure conditions. The sorbent was regenerated by using low-temperature heat, with a reduced thermal energy requirement. In ref. [10] novel absorbents were studied using both single and mixed amine-based absorbents. Experimental results indicate that most absorbents tested have a poor performance as compared to MEA except for aqueous 2-(2-Aminoethylamine)ethanol (AEEA), which shows a promising performance. Ref. [11] presents a review about the impact of uncertainty in the sorbent thermo-physical properties on the design and operation of components and processes involved in $\mathrm{CO}_{2}$ capture.

$\mathrm{CO}_{2}$ capture processes using dry solid sorbents capable of capturing $\mathrm{CO}_{2}$ from flue gas streams by

physical adsorption show potential advantages compared with other conventional $\mathrm{CO}_{2}$ capture 
systems using aqueous amine solvents [12]. Thus, a variety of promising adsorbents such as activated carbonaceous materials, microporous/mesoporous silica or zeolites, carbonates, and polymeric resins have been proposed in the recent literature [12]. As a common feature, these solid sorbents require very small amounts of heat for regeneration although their capture capacity is generally low. Ref [13] proposes the use of power plant's waste heat for $\mathrm{CO}_{2}$ capture by nanomaterials porperly designed to overcome the competitive adsorption of $\mathrm{CO}_{2}$ and $\mathrm{H}_{2} \mathrm{O}$.

The Calcium-Looping process is a promising $2^{\text {nd }}$ generation post-combustion process validated at the pilot level (1-2 $\left.\mathrm{MW}_{\text {th }}\right)$ that uses Calcium Oxide $(\mathrm{CaO})$ derived from cheap $(\sim 10 € /$ ton $)$ and abundant natural limestone to capture $\mathrm{CO}_{2}$ from flue gas. The process is based on the reversible carbonation/calcination chemical reaction at high temperatures [14]:

$$
\mathrm{CaO}_{(s)}+\mathrm{CO}_{2(g)} \leftrightarrows \mathrm{CaCO}_{3(s)} \quad \Delta H_{298 \mathrm{~K}}=-178 \frac{\mathrm{kJ}}{\mathrm{mol}}
$$

Carbonation proceeds at a satisfactory fast rate at temperatures in the range $625-680^{\circ} \mathrm{C}$ while the reverse calcination reaction should be carried out at $900-950^{\circ} \mathrm{C}$ under high $\mathrm{CO}_{2}$ partial pressure [14]. The dry sorbent is repeatedly cycled between two reactors. In one reactor (carbonator) carbonation of $\mathrm{CaO}$ particles serves to capture $\mathrm{CO}_{2}$ from the flue gas. The carbonated particles are then circulated into another reactor (calciner) where sorbent regeneration takes place by calcination. To close the cycle, the regenerated $\mathrm{CaO}$ particles are returned back into the carbonator, leaving a concentrated stream of $\mathrm{CO}_{2}$ in the calciner ready for compression, transport and sequestration. However, a main drawback of this process is the progressive deactivation of $\mathrm{CaO}$ particles mainly due to marked sintering in the high temperature calcination stage, which requires a large make-up of fresh limestone thus increasing the energy penalty of the process taking into account the high temperatures at which it must be carried out to enhance the reaction kinetics.

Concerning the penalty imposed by the capture system, ref [15] examines potential design routes for the capture, transport and storage of $\mathrm{CO}_{2}$ in power plants. Around $90 \%$ of operational carbon emissions could be captured with an energy penalty between 14 and $300 \%$ and rises by $27-142 \%$ of electricity cost [16]. However, $\mathrm{CO}_{2}$ capture system integration, with an adequate heat and work integration would result in significant energy savings [17] . The $\mathrm{CO}_{2}$ capture installation requires large amounts of heat for solvent regeneration in appropriate quantity and quality, a cooling system to discharge waste heat and additional power to drive $\mathrm{CO}_{2}$ compressor and auxiliary equipment (pump, fans). In [18] the steam to CCU is extracted from IP/LP crossover pipe showing the high impact of the design IP/LP crossover pressure on the power unit efficiency.

Integration with solar could by a driving factor to favor $\mathrm{CO}_{2}$ capture implementation at the commercial scale. Ref [19] studies flexible operation of solvent-based capture for three types of plants obtaining the highest revenue to electricity ratio in the case where solar repowering was used for power boosting. Ref [20] analyzes the use of solar energy to provide the energy of the capture system. A CaL based capture system assisted by solar energy is assessed in [20] for reducing the global system efficiency penalty.

CCS feasibility could be fostered by integration of the capture system with other processes and valuable chemicals. Ref [21] suggests a method for combining CCS and biofuel production using $\mathrm{CO}_{2}$ as a feedstock. [22]. A significant part of the cost for CCS is related to the compression of the captured $\mathrm{CO}_{2}$, however the conditions for carbon capture and utilization (CCU) can reduce the parasitic energy consumption. Ref [27] addresses the critical technologies in $\mathrm{CO}_{2}$ capture, transport, utilization and storage and proposes technical priorities by evaluating critical indexes such as the objective contribution rate and technical maturity. 
Among the carbon capture technologies in a research and development (R\&D) phase [23], one of the most promising $\mathrm{CO}_{2}$ capture processes is the dry carbonate process, which uses $\mathrm{Na}_{2} \mathrm{CO}_{3}$ (sodium carbonate also known as soda ash) as sorbent to separate $\mathrm{CO}_{2}$ from others flue gases. The process is based on the reversible chemical reaction [24]:

$$
\mathrm{Na}_{2} \mathrm{CO}_{3(s)}+\mathrm{CO}_{2}(\mathrm{~g})+\mathrm{H}_{2} \mathrm{O}_{(\mathrm{g})} \leftrightarrows 2 \mathrm{NaHCO}_{3} \quad \Delta H=-129,1 \frac{\mathrm{kJ}}{\mathrm{mol}}
$$

Equal molar quantities of $\mathrm{CO}_{2}$ and $\mathrm{H}_{2} \mathrm{O}$ are produced during sorbent regeneration, and pure $\mathrm{CO}_{2}$ suitable for use or sequestration is available after condensation of the $\mathrm{H}_{2} \mathrm{O}$. In contrast with the Calcium-Looping process, the carbonation reaction in the dry carbonate process takes place efficiently at relatively low temperatures $\left(60-70^{\circ} \mathrm{C}\right)$, which is below the typical flue gas temperature. At these temperatures, the capture efficiency can be as large as $90 \%$. Moreover, the required sorbent regeneration temperature is not high $\left(120-200^{\circ} \mathrm{C}\right)$ allowing the use of medium temperature heat sources. $\mathrm{Na}_{2} \mathrm{CO}_{3}$ is an abundant and relatively cheap $(\sim 100 € /$ ton $)$ natural mineral lacking serious problems of degradation, toxicity or corrosiveness at the working temperatures of the process $[1,25]$. The research triangle institute (RTI) has designed and constructed a Dry Carbonate based prototype unit [26] showing a number of potential advantages over MEA systems such as [30] : i) lower total regeneration energy requirement; ii) less energy requirement also to operate due to lower pressure drop; iii) Modest temperatures of operation and noncorrosive reactants allowing standard equipment and materials of construction; iv) more stable and cheaper sorbent than amines.

Reaction (2) is also at the basis of the Solvay process to produce sodium bicarbonate (NaHCO3 also known as baking soda) through the reaction of calcium carbonate, sodium chloride, ammonia, and carbon dioxide in water. In this process (Solvay), the initial reaction of $\mathrm{CO}_{2}$ with an aqueous solution of sodium hydroxide to produce sodium carbonate is:

$$
\mathrm{CO}_{2}+2 \mathrm{NaOH} \rightarrow \mathrm{Na}_{2} \mathrm{CO}_{3}+\mathrm{H}_{2} \mathrm{O}
$$

Further addition of $\mathrm{CO}_{2}$ yields $\mathrm{NaHCO}_{3}$ through reaction (2), which at sufficiently high concentration precipitates out of the solution. Sodium hydroxide $(\mathrm{NaOH})$ is mainly produced from electrolysis $\left(2 \mathrm{NaCl}(\mathrm{aq})+2 \mathrm{H}_{2} \mathrm{O}(\mathrm{l}) \rightarrow \mathrm{H}_{2}(\mathrm{~g})+\mathrm{Cl}_{2}(\mathrm{~g})+2 \mathrm{NaOH}(\mathrm{aq}), \Delta \mathrm{H}_{298 \mathrm{~K}}=422 \mathrm{~kJ} / \mathrm{mol}\right)$ [27]. This involves a certain amount of waste energy to produce $\mathrm{NaHCO}_{3}$ as benefit. $\mathrm{NaHCO}_{3}$ is also produced commercially by a similar method using $\mathrm{Na}_{2} \mathrm{CO}_{3}$ obtained from naturally occurring mineral trona, which is dissolved in water and treated with $\mathrm{CO}_{2}$ [25]. This process avoids the use of electrolysis for $\mathrm{NaOH}$ production, but a little amount of energy is still required for trona dissociation $(133,9 \mathrm{~kJ} / \mathrm{mol})$.

In the present manuscript a novel CCU concept is introduced, which combines the production of $\mathrm{NaHCO}_{3}$ with the dry carbonation process for $\mathrm{CO}_{2}$ capture and is assisted by renewable energy sources for sorbent regeneration (solar thermal power or biomass). The structure of the manuscript is the following. First, the current state of the art technology for sodium bicarbonate production from trona decomposition is described. Then the concept of $\mathrm{CO}_{2}$ capture and sodium bicarbonate production for $\mathrm{CO}_{2}$ fixation in a valuable chemical product is described. $\mathrm{Na}_{2} \mathrm{CO}_{3}, \mathrm{CO}_{2}$ and $\mathrm{H}_{2} \mathrm{O}$ are obtained from trona decomposition. These three components, together with a relevant fraction of $\mathrm{CO}_{2}$ from the capture system are used for sodium bicarbonate production. The integration scheme is applied to a small $15 \mathrm{MW}_{\mathrm{el}}$ coal power plant or, equivalently, to a fraction of the flue gas from a bigger size plant. The novel concept of this manuscript consists of the synergistic combination of the dry carbonate process with sodium bicarbonate production starting from a raw natural material such as trona. This study shows that the penalty imposed by the capture system can be mitigated from the production of a valuable material such as sodium bicarbonate with an economic return. The results 
obtained in this preliminary analysis demosntrate the environmental and economic interest of the proposed concept

\section{Trona mineral}

Trona consists mainly of sesquicarbonate sodium (systematic name is trisodium hydrogendicarbonate) having the chemical formula:

$$
\mathrm{Na}_{2} \mathrm{CO}_{3} \cdot \mathrm{NaHCO}_{3} \cdot 2 \mathrm{H}_{2} \mathrm{O}
$$

As specified in Table 1, natural trona is composed of approximately $46 \% \mathrm{Na}_{2} \mathrm{CO}_{3}$ and $35 \% \mathrm{NaHCO}_{3}$ being relatively abundant in nature. They are widely distributed around the world. Among other places they are found in Wyoming [28,29] , Tanzania [30], Namib [31], Turkey [32], China [33]. Calcination and dehydration of raw trona in industrial processes are applied for different purposes: to eliminate carbonate for reducing acid consumption if an acidic treatment is to be applied, to decrease the weight of the material for reducing transportation costs in the case that it involves hydration in large quantities, or as a necessary step in a chemical process such as the production of $\mathrm{Na}_{2} \mathrm{CO}_{3}$, which is the main focus of the current manuscript.

In the production of $\mathrm{Na}_{2} \mathrm{CO}_{3}$ from trona, the monohydrate process is the most commonly used method. The first step of this method is thermal decomposition of the mineral, which yields $\mathrm{Na}_{2} \mathrm{CO}_{3}$ via the following reaction $[34,35]$ :

$$
\begin{gathered}
2\left(\mathrm{Na}_{2} \mathrm{CO}_{3} \cdot \mathrm{NaHCO}_{3} \cdot 2 \mathrm{H}_{2} \mathrm{O}\right)_{(s)} \rightarrow 3 \mathrm{Na}_{2} \mathrm{CO}_{3(s)}+\mathrm{CO}_{2(g)}+5 \mathrm{H}_{2} \mathrm{O}_{(\mathrm{g})} \\
\Delta \mathrm{H}_{298 \mathrm{~K}}=133,9 \frac{\mathrm{KJ}}{\mathrm{mol}}
\end{gathered}
$$

Table 1. Natural trona composition [34]

\begin{tabular}{l|l}
\hline Component & Wt\% \\
\hline $\mathrm{Na}_{2} \mathrm{CO}_{3}$ & 46,53 \\
\hline $\mathrm{NaHCO}_{3}$ & 34,82 \\
\hline $\mathrm{Na}_{2} \mathrm{SO}_{4}$ & 0,568 \\
\hline insolubles & 2,98 \\
\hline hydration water & 14,92 \\
\hline others & 0,182 \\
\hline
\end{tabular}

Trona-phase equilibrium diagrams for low and high temperature regions have been analysed in detail in [36]. Trona is stable at temperatures up to $57{ }^{\circ} \mathrm{C}$ under dry conditions. Intermediate salts such as wegschiderite $\left(\mathrm{Na}_{2} \mathrm{CO}_{3} \cdot 3 \mathrm{NaHCO}_{3}\right)$ and sodium monohydrate $\left(\mathrm{Na}_{2} \mathrm{CO}_{3} \cdot \mathrm{H}_{2} \mathrm{O}\right)$ are produced between $57{ }^{\circ} \mathrm{C}$ and $160{ }^{\circ} \mathrm{C}[34,37]$. Above $160{ }^{\circ} \mathrm{C}$, trona decomposes into $\mathrm{Na}_{2} \mathrm{CO}_{3}$ and $\mathrm{NaHCO}_{3} . \mathrm{NaHCO}_{3}$ decomposes to $\mathrm{Na}_{2} \mathrm{CO}_{3}, \mathrm{H}_{2} \mathrm{O}$ and $\mathrm{CO}_{2}$ in the temperature range of $10{ }^{\circ} \mathrm{C}-200{ }^{\circ} \mathrm{C}$ [38]. Reaction kinetics is fast at $200^{\circ} \mathrm{C}$ [39]:

$$
2 \mathrm{NaHCO}_{3} \rightarrow \mathrm{Na}_{2} \mathrm{CO}_{3}+\mathrm{H}_{2} \mathrm{O}+\mathrm{CO}_{2}
$$

Thus, the final decomposition of trona generates $\mathrm{Na}_{2} \mathrm{CO}_{3}, \mathrm{CO}_{2}$ and $\mathrm{H}_{2} \mathrm{O}$.

\section{Sodium bicarbonate production}


The novel concept presented in this manuscript combines $\mathrm{CO}_{2}$ capture and the production of $\mathrm{NaHCO}_{3}$ at low temperature using for both processes natural trona as raw material. $\mathrm{CO}_{2}$ capture is realized via the reaction expressed by Eq. (2). This section briefly reviews $\mathrm{NaHCO}_{3}$ production from raw trona as currently applied in industry and the reactions involved that will be used in this work.

In the $\mathrm{NaHCO}_{3}$ production process, crushed raw trona is fed into a vertical hollow tubular vessel with a perforated bottom that separates an upper fluidizing chamber from a lower plenum chamber. A gas stream is introduced into the plenum chamber through the perforated bottom to fluidize crushed trona. Part of the charge remains in suspension while the decomposition gases such as $\mathrm{H}_{2} \mathrm{O}$ and $\mathrm{CO}_{2}$ are redirected to the carbonator for $\mathrm{NaHCO}_{3}$ production. The fluidized bed reactor acts both as a calciner for the crushed trona and as a separator to remove fine particles of crushed trona from the coarse portion of the charge remaining in fluid suspension in the fluidized bed reactor. Thus, fine particles of crushed trona become entrained in the effluent gas and exit the fluidized bed before they become calcined. The thermal energy required to achieve the conversion of crude trona to $\mathrm{Na}_{2} \mathrm{CO}_{3}$ is supplied by heating the fluidizing gas or by placing heating means within or around the bed in order to attain a temperature of $125^{\circ}-225^{\circ} \mathrm{C}$ [40]. The next step is to take the intermediate $\mathrm{Na}_{2} \mathrm{CO}_{3}$ solution into a centrifuge, which separates the liquid from the crystals. The crystals are then dissolved in a soda ash solution made by the manufacturer in a rotary dissolver, thereby becoming a saturated solution. This solution is filtered to remove any nonsoluble materials and is then pumped through a feed tank to the top of a carbonating tower. Purified $\mathrm{CO}_{2}$ is introduced into the bottom of the tower and held under pressure. As the saturated sodium solution moves through the tower, it cools down and reacts with $\mathrm{CO}_{2}$ to form $\mathrm{NaHCO}_{3}$ crystals. These crystals are collected at the bottom of the tower and transferred to another centrifuge, where the excess solution (filtrate) is filtered out. The crystals are then washed in a bicarbonate solution, forming a cake-like substance ready for drying. The filtrate removed from the centrifuge is recycled to the rotary dissolver, where it is used to saturate more intermediate soda ash crystals. The washed filter cake is then dried on either a continuous belt conveyor or in a vertical tube drier.

A key step in the process occurs in the carbonating tower. Here, the saturated $\mathrm{Na}_{2} \mathrm{CO}_{3}$ solution moves from the top of the tower downwards. As it falls, the solution cools down and reacts with $\mathrm{CO}_{2}$ to form $\mathrm{NaHCO}_{3}$ crystals. After filtering, washing, and drying, the crystals are sorted by particle size and packaged appropriately. Trona decomposition and $\mathrm{Na}_{2} \mathrm{CO}_{3}$ carbonation involve several reactions. Dissociation reactions of trona and $\mathrm{NaHCO}_{3}$ are:

$$
\begin{aligned}
& 2\left(\mathrm{Na}_{2} \mathrm{CO}_{3} \cdot \mathrm{NaHCO}_{3} \cdot 2 \mathrm{H}_{2} \mathrm{O}\right)_{(s)} \leftrightarrows 3 \mathrm{Na}_{2} \mathrm{CO}_{3(s)}+\mathrm{CO}_{2_{(g)}}+5 \mathrm{H}_{2} \mathrm{O}_{(g)} \leftrightarrows \\
& 3 \mathrm{Na}^{+}+\mathrm{CO}_{3}^{--}+\mathrm{HCO}_{3}^{-}+2 \mathrm{H}_{2} \mathrm{O}
\end{aligned}
$$

$$
\mathrm{NaHCO}_{3} \leftrightarrows \mathrm{Na}^{+}+\mathrm{HCO}_{3}^{-}
$$

In the process, a number of other salts can be also formed such as sodium carbonate decahydrate $\left(\mathrm{Na}_{2} \mathrm{CO}_{3} \cdot 10 \mathrm{H}_{2} \mathrm{O}\right)$, sodium carbonate heptahydrate $\left(\mathrm{Na}_{2} \mathrm{CO}_{3} \cdot 10 \mathrm{H}_{2} \mathrm{O}\right)$, sodium carbonate monohydrate $\left(\mathrm{Na}_{2} \mathrm{CO}_{3} .10 \mathrm{H}_{2} \mathrm{O}\right)$ and Wegsheider's salt $\left(\mathrm{Na}_{2} \mathrm{CO}_{3} .3 \mathrm{NaHCO}_{3}\right)$. Thus, other possible reactions are:

$$
\mathrm{Na}_{2} \mathrm{CO}_{3} \cdot 10 \mathrm{H}_{2} \mathrm{O} \leftrightarrows 2 \mathrm{Na}^{+}+\mathrm{CO}_{3}^{-}+10 \mathrm{H}_{2} \mathrm{O}
$$

$$
\mathrm{Na}_{2} \mathrm{CO}_{3} \cdot 7 \mathrm{H}_{2} \mathrm{O} \leftrightarrows 2 \mathrm{Na}^{+}+\mathrm{CO}_{3}^{-}+7 \mathrm{H}_{2} \mathrm{O}
$$

$$
\mathrm{Na}_{2} \mathrm{CO}_{3} \cdot \mathrm{H}_{2} \mathrm{O} \leftrightarrows 2 \mathrm{Na}^{+}+\mathrm{CO}_{3}^{-}+\mathrm{H}_{2} \mathrm{O}
$$

$$
\mathrm{Na}_{2} \mathrm{CO}_{3} \cdot 3 \mathrm{NaHCO}_{3} \leftrightarrows 5 \mathrm{Na}^{+}+\mathrm{CO}_{3}^{--}+3 \mathrm{HCO}_{3}^{-}
$$

$$
2\left(\mathrm{Na}_{2} \mathrm{CO}_{3} \cdot \mathrm{NaHCO}_{3} \cdot 2 \mathrm{H}_{2} \mathrm{O}\right) \leftrightarrows 3 \mathrm{Na}^{+}+\mathrm{CO}_{3}^{--}+\mathrm{HCO}_{3}^{-}+2 \mathrm{H}_{2} \mathrm{O}
$$


To model the dependence of the equilibrium constants $(\mathrm{Ks})$ for the dissociation reactions of the different salts involved in $\mathrm{NaHCO}_{3}$ production we have used a polynomial equation:

$$
\ln K_{s}=A+\frac{B}{T}+C \ln (T)+D T
$$

which provides a good fit to experimental curves shown in [36] $\left(R^{2}>0.99\right)$. Best fittings parameters are given in Table 2.

Table 2. Best fitting parameters used in the model for the equilibrium constant $\mathrm{K}_{\mathrm{s}}$ (Eq. 15) of the reactions involved in $\mathrm{NaHCO}_{3}$ production from raw trona.

\begin{tabular}{c|c|c|c|c}
\hline & $\mathrm{A}$ & $\mathrm{B}$ & $\mathrm{C}$ & $\mathrm{D}$ \\
\hline $\mathrm{REACTIONS}$ & & & & \\
\hline $\mathrm{CO}_{2}+2 \mathrm{H}_{2} \mathrm{O} \leftrightarrows \mathrm{H}_{3} \mathrm{O}^{+}+\mathrm{HCO}_{3}^{-}$ & 231.47 & -12092.7 & -36.78 & 0 \\
\hline $\mathrm{HCO}_{3}^{-}+\mathrm{H}_{2} \mathrm{O} \leftrightarrows \mathrm{H}_{3} \mathrm{O}^{+}+\mathrm{CO}_{3}^{-}$ & 216.05 & -1243.7 & -35.48 & 0 \\
\hline $\mathrm{NaHCO}_{3} \leftrightarrows \mathrm{Na}^{+}+\mathrm{HCO}_{3}^{-}$ & -63.26 & -1308.41 & 13.48 & -0.034 \\
\hline $\mathrm{Na}_{2} \mathrm{CO}_{3} \leftrightarrows 2 \mathrm{Na}^{+}+\mathrm{CO}_{3}^{-}$ & -548.32 & 18070.74 & 94.75 & -0.165 \\
\hline $\mathrm{Na}_{2} \mathrm{CO}_{3} \cdot \mathrm{H}_{2} \mathrm{O} \leftrightarrows 2 \mathrm{Na}^{+}+\mathrm{CO}_{3}^{-}+\mathrm{H}_{2} \mathrm{O}$ & 281.77 & -9970.6 & -44.56 & 0.0221 \\
\hline $\mathrm{Na}_{2} \mathrm{CO}_{3} \cdot 7 \mathrm{H}_{2} \mathrm{O} \leftrightarrows 2 \mathrm{Na}^{+}+\mathrm{CO}_{3}^{-}+7 \mathrm{H}_{2} \mathrm{O}$ & 484.91 & -18935 & -80.12 & 0.114 \\
\hline $\mathrm{Na}_{2} \mathrm{CO}_{3} \cdot 10 \mathrm{H}_{2} \mathrm{O} \leftrightarrows 2 \mathrm{Na}^{+}+\mathrm{CO}_{3}^{-}+10 \mathrm{H}_{2} \mathrm{O}$ & 1165.01 & -37.81 & -200.08 & 0.335 \\
\hline $2\left(\mathrm{Na}_{2} \mathrm{CO}_{3} \cdot \mathrm{NaHCO}_{3} \cdot 2 \mathrm{H}_{2} \mathrm{O} \leftrightarrows 5 \mathrm{Na}^{+}+\mathrm{CO}_{3}^{--}\right.$ & & & & \\
$+\mathrm{HCO}-\mathrm{HO}_{3}^{-}+2 \mathrm{H}_{2} \mathrm{O}$ & 277.24 & -14523.8 & -41.0 & 0.0085 \\
\hline $\mathrm{Na}_{2} \mathrm{CO}_{3} \cdot 3 \mathrm{NaHCO}_{3} \leftrightarrows 5 \mathrm{Na}^{+}+\mathrm{CO}_{3}^{--}+3 \mathrm{HCO}_{3}^{-}$ & -1209.46 & 29113.05 & 213.72 & -0.363 \\
\hline
\end{tabular}

For example, at $200^{\circ} \mathrm{C}$, it is $\mathrm{Ks}>1$ for the $\mathrm{NaHCO}_{3}$ dissociation reaction and hence the reaction is shifted to dissociation while for $\mathrm{Na}_{2} \mathrm{CO}_{3}$ dissociation it is $\mathrm{Ks}<1$ indicating that $\mathrm{Na}_{2} \mathrm{CO}_{3}$ dissociation is not thermodynamically favored at this temperature. Equilibrium between carbonate and bicarbonate ions in the aqueous solution determines the stable solid phase in a saturated solution and the corresponding solubility concentrations of carbonate and bicarbonate. This equilibrium is strongly affected by the $\mathrm{CO}_{2}$ partial pressure. At $\mathrm{T}<80{ }^{\circ} \mathrm{C}\left(\mathrm{Ks}_{\mathrm{NaHCO}_{3}}<1\right)$ and ambient $\mathrm{CO}_{2}$ partial pressure, solid bicarbonate (nahcolite) is the thermodynamically stable solid [41]. Equilibrium between the dissolved bicarbonate and dissolved carbonate establishes itself by sorption of $\mathrm{CO}_{2}$.

\section{Integration of $\mathrm{NaHCO}_{3}$ production and $\mathrm{CO}_{2}$ capture}

In this section a novel concept of integration of the $\mathrm{NaHCO}_{3}$ production process above described and the dry carbonate $\mathrm{CO}_{2}$ capture process is presented. The integration is originally conceived for its application in a coal fired power plant (CFPP), which is retrofitted with the dry carbonate process using $\mathrm{Na}_{2} \mathrm{CO}_{3}$ for $\mathrm{CO}_{2}$ capture, although it can be used in other industrial applications with $\mathrm{CO}_{2}$ emissions. The flow diagram of this integration is shown in Figure 1. Part of the $\mathrm{Na}_{2} \mathrm{CO}_{3}$ produced by trona calcination is used as sorbent make-up in the $\mathrm{CO}_{2}$ capture process while a fraction of the $\mathrm{CO}_{2}$ released from sorbent regeneration, together with the fraction of $\mathrm{CO}_{2}$ derived from trona dissociation $\left(0.5 \mathrm{~mol}_{\mathrm{CO} 2} / \mathrm{mol}_{\text {trona }}\right)$, is utilized to produce in the carbonating tower $\mathrm{NaHCO}_{3}$ suitable for sale. As Figure 1 shows $\mathrm{H}_{2} \mathrm{O}$ is used in the calciner for trona decomposition and carbonation of the flue gas stream. $\mathrm{H}_{2} \mathrm{O}$ is generated in the carbonating tower during $\mathrm{NaHCO}_{3}$ production and in the $\mathrm{NaHCO}_{3}$ regenerator. An optimized integration would recirculate these hot water streams between these systems, regenerator to carbonator in the CCS system, and from the carbonating tower to the calciner in the $\mathrm{NaHCO}_{3}$ production system. Calcination of trona and sorbent regeneration are assisted by medium temperature heat, which could be available from renewable sources such as solar thermal or biomass. If these renewable sources are used, the global system (power plant plus capture of $\mathrm{CO}_{2}$, 
part of which is stored and the rest used for $\mathrm{NaHCO}_{3}$ production) becomes a near zero $\mathrm{CO}_{2}$ emissions system.

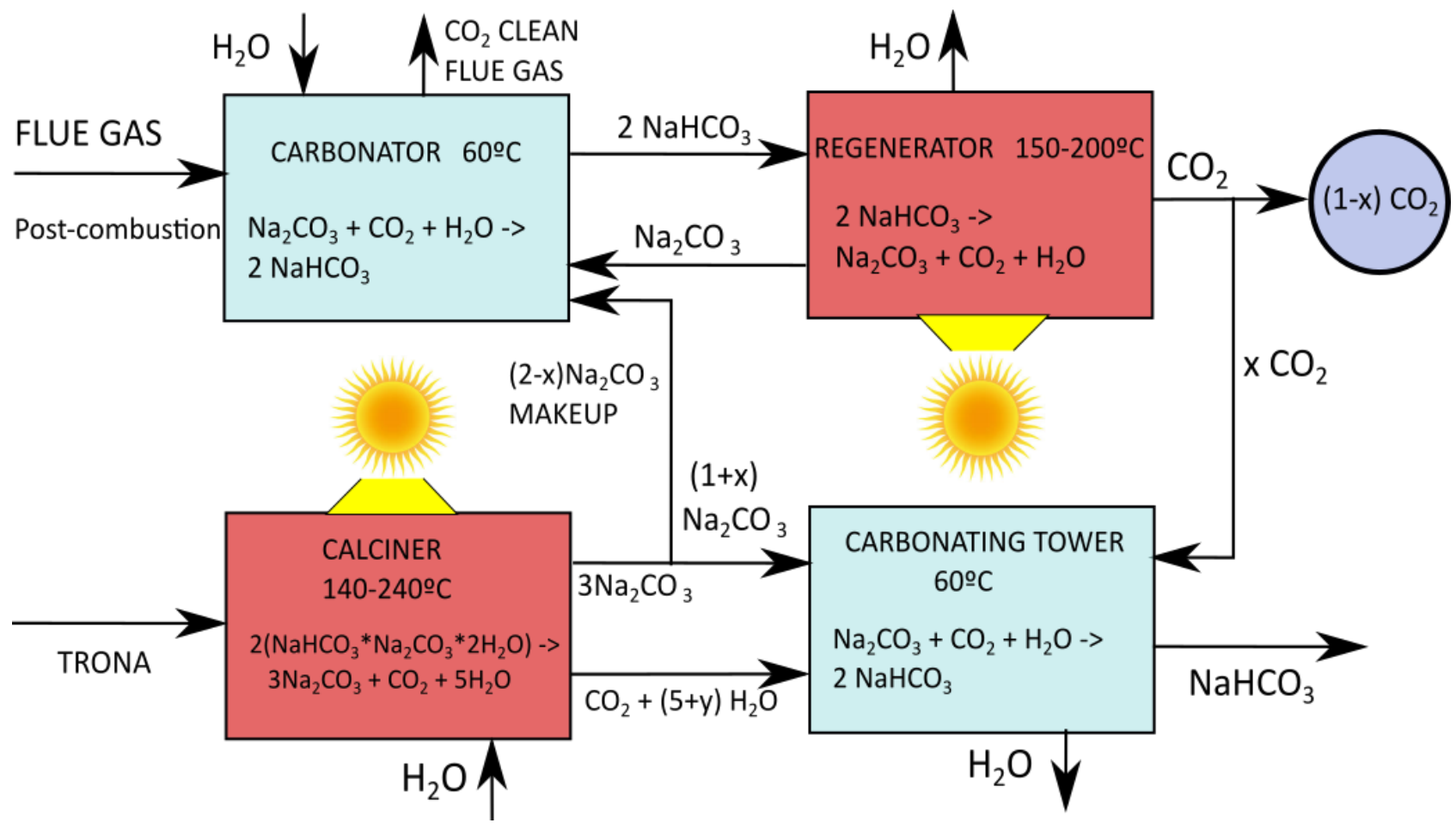

Figure 1. Flow diagram of the research triangle institute (RTI) dry carbonate process for $\mathrm{CO}_{2}$ capture coupled to $\mathrm{NaHCO}_{3}$ production using raw trona and assisted by medium temperature solar thermal power.

Figure 2 illustrates a Sankey diagram where the different routes followed by the $\mathrm{CO}_{2}$ are detailed.

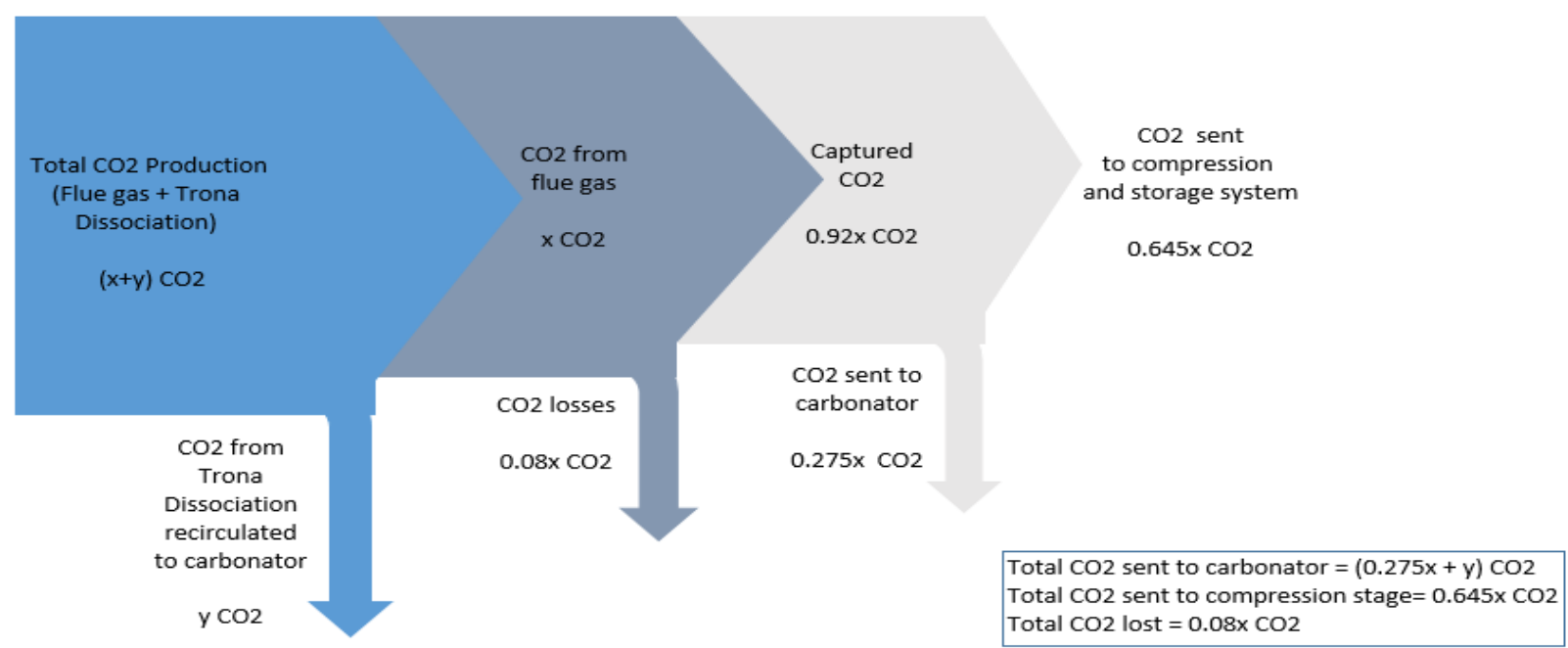

Figure 2. Sankey diagram of $\mathrm{CO}_{2}$ routes in the overall process

As Figure 2 shows an amount of about $35 \%$ of $\mathrm{CO}_{2}$ produced by the CFPP is employed for $\mathrm{NaHCO}_{3}$ production while the rest is sent to the compression system and could be stored or eventually utilized for others purposes. 


\section{Reference power plant}

This section describes the main characteristics of the CFPP used in this work as reference case. CFPP flue gases are characterized by a dilute concentration of $\mathrm{CO}_{2}$ at large volumetric flow and ambient pressure, which poses a technological challenge for $\mathrm{CO}_{2}$ capture For the $15 \mathrm{MW}_{\text {el }}$ generated in the pulverized coal-fired (PC) power plant used in our study, the exhaust gases stream is $830 \mathrm{~m}^{3}$ per minute with a $\mathrm{CO}_{2}$ concentration between $10 \%$ and $15 \%$ in volume [42]. Assuming standard performance of equipment, the pulverized coal-fired boiler combusts 6.1 tons per hour (tph) of coal and generates $44.7 \mathrm{MW}_{\text {th }}$ (HHV). The boiler output provides $39.7 \mathrm{MW}_{\text {th }}$, which yields a boiler efficiency of $88.6 \%$. Since the present work is focused on the postcombustion system analysis and given the complexity and proprietary nature of power plant steam turbine cycles, a general $42 \%$ thermal to electric steam cycle efficiency is assumed [43], which leads to $16.67 \mathrm{MW}_{\text {el }}$ generated. In addition, a $10 \%$ in-house power plant electricity is consumed resulting in a net electrical generation of $15 \mathrm{MW}_{\mathrm{el}}$ delivered to the grid.

The relatively small size of the reference CFPP $\left(15 \mathrm{MW}_{\mathrm{el}}\right)$ has been chosen with the purpose of storing the captured $\mathrm{CO}_{2}$ in tanks of reasonable volume to be ready for utilization. This size can be representative of small coal power plants or for dealing with a fraction of the exhaust gases of bigger plants. Main data for a plant of this reference CFPP are shown in Table 3. Composition of the flue gas from the plant used for the analysis is detailed in Table 4.

Table 3: Power consumption for the reference CFPP [42,43]

\begin{tabular}{l|l|l}
\hline Item & Magnitude & Unit \\
\hline Coal consumption & 6.1 & $\mathrm{t} / \mathrm{h}$ \\
\hline Air in & 69.2 & $\mathrm{t} / \mathrm{h}$ \\
\hline Gross power introduced & 44.7 & $\mathrm{MW}_{\text {th }}$ \\
\hline Net power introduced & 39.7 & $\mathrm{MW}_{\text {th }}$ \\
\hline Net Power Produced & 15 & $\mathrm{MW}_{\mathrm{el}}$ \\
\hline Net efficiency & 33.5 & $\%$ \\
\hline
\end{tabular}

Table 4: Flue gas flow composition from the reference CFPP $[42,43]$.

\begin{tabular}{c|c|c}
\hline Coal flue gas component & Mole Flow $(\mathrm{kmol} / \mathrm{h})$ & Mass Flow(t/h) \\
\hline $\mathrm{N}_{2}$ & 1715.42 & 52.97 \\
\hline $\mathrm{CO}_{2}$ & 308.56 & 13.60 \\
\hline $\mathrm{H}_{2} \mathrm{O}$ & 147.19 & 2.94 \\
\hline $\mathrm{O}_{2}$ & 78.18 & 2.76 \\
\hline $\mathrm{CO}$ & 14.07 & 0.39 \\
\hline $\mathrm{NO}$ & 13.54 & 0.45 \\
\hline $\mathrm{SO}_{2}$ & 3.75 & 0.26 \\
\hline
\end{tabular}

The use of the dry carbonate process in a CFPP for $\mathrm{CO}_{2}$ capture is described in [10]. An optimized integration with solar thermal energy is schematized in figure 3. Alternatively, the heat source could be either biomass or coal. Overall, the dry carbonate process yields a $\mathrm{CO}_{2}$ removal efficiency of $92 \%$ (assuming a fixed value for $\mathrm{Na}_{2} \mathrm{CO}_{3}$ conversion to $\mathrm{NaHCO}_{3}$ of $\mathrm{X}=0.75$ ) and utilizes $43 \mathrm{ton} / \mathrm{hr}$ of $\mathrm{Na}_{2} \mathrm{CO}_{3}$ as $\mathrm{CO}_{2}$ sorbent to remove $12.5 \mathrm{t} / \mathrm{h}$ of $\mathrm{CO}_{2}$ in a continuous cycle. A heat exchanger (HEATEX1) between the flue gas leaving the power coal plant and the flow exiting the carbonator is used for cooling the flue gas. Another heat exchanger (HEATEXCH) is interposed between the 
incoming and the outgoing flow in the regenerator. Both heat exchangers serve to increase significantly the total efficiency of the plant. They allow to reduce the heat required for sorbent regeneration by about $10 \%$ with a thermal flow exchanged of $1,45 \mathrm{MW}$ th $(0.8 \mathrm{MW}$ th+ $0.65 \mathrm{MW}$ th). This makes possible working with different operating conditions in the regenerator $\left(200{ }^{\circ} \mathrm{C}\right.$ in the best case scenario and $140^{\circ} \mathrm{C}$ with solar radiation support). With this configuration the heat requirement, in the case the working condition in the regenerator are set equal to $\mathrm{T}=200^{\circ} \mathrm{C}$ and $\mathrm{p}=1,01$ bar, is about 11,4 MWth (the theoretical value for the heat required using $\Delta H=129,09 \frac{\mathrm{kJ}}{\mathrm{mol}}$ at $\mathrm{T}=298$ $\mathrm{K}$ is $10,25 \mathrm{MW}$ th ).

The $\mathrm{Na}_{2} \mathrm{CO}_{3}$ make-up flow rate is $0.3 \mathrm{ton} / \mathrm{hr}$, the heat required for $\mathrm{Na}_{2} \mathrm{CO}_{3}$ regeneration is around 11.4 MWth and the power consumption for $\mathrm{CO}_{2}$ compression and solid conveying is $1.58 \mathrm{MWel}$ (Table 5). Power demand for solid separation in two stages centrifugation can be estimated as 0.3 MWel by taking as reference a high efficiency centrifuge used as salt separator. Thus, the total efficiency of the CFPP retrofitted with the dry carbonate process drops from $33.5 \%$ to $24 \%$ due to the penalty in power and additional heat required. If medium temperature solar thermal energy is used as energy input for sorbent regeneration, and taking thus into account only the penalty in power consumption, the economic efficiency, defined in basis of the operation costs including fuel, decreases just to about $30 \%$.

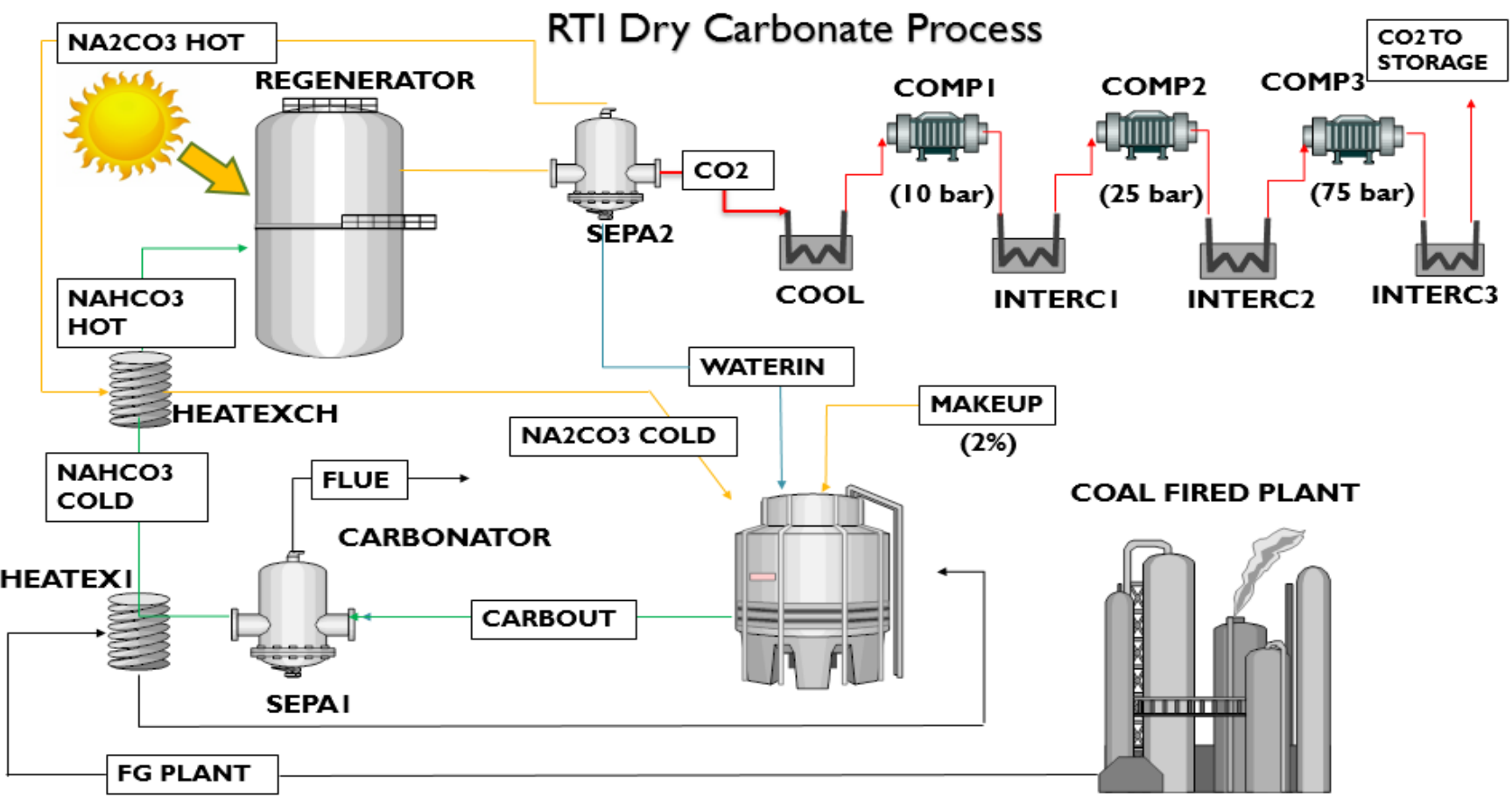

Figure 3. Integration of the RTI dry carbonate process into a CFPP for $\mathrm{CO}_{2}$ capture [44].

Table 5. Power consumption for a $15 \mathrm{MW}_{\mathrm{el}} \mathrm{CFPP}$ with integrated RTI dry carbonate process for $\mathrm{CO}_{2}$ capture.

\begin{tabular}{l|l|l}
\hline & Power production & Power consumption \\
\hline CFFP & $15 \mathrm{MW}_{\text {el }}$ & $44.7 \mathrm{MW}_{\text {th }}$ \\
\hline Regenerator & & $11.4 \mathrm{MW}_{\text {th }}$ \\
\hline COMP & & $1.33 \mathrm{MW}_{\mathrm{el}}$ \\
\hline Wsolid & & $0.25 \mathrm{MW}_{\mathrm{el}}$ \\
\hline Centrifugation & & $0.3 \mathrm{MW}_{\mathrm{el}}$ \\
\hline Net Power & $13.12 \mathrm{MW}_{\mathrm{el}}$ & \\
\hline Total heat requirement & & $56.1 \mathrm{MW}_{\text {th }}$ \\
\hline
\end{tabular}


To achieve a near zero $\mathrm{CO}_{2}$ emissions global system, renewable energy must be used for heating the calciner, either solar or biomass. In the case of solar, and to take into account its discontinuous availability, different options for heat storage can be considered such as: i) heat storage using tanks with pressurized water/steam. For instance a thermal storage of about 3 hours of steam can be obtained with the support of three tanks of $350 \mathrm{~m}^{3}$; ii) molten salts tanks; iii) synthetic oils; iv) a combination with a biomass boiler for supporting heat requirements of the post-combustion system.

Regarding the required $\mathrm{CO}_{2}$ storage volume, a total flow rate of $68000 \mathrm{~m}^{3} / \mathrm{h}$ in the carbonator must be processed. Assuming a residence time of $15 \mathrm{~s}$, a total storage volume of $270 \mathrm{~m}^{3}$ would be sufficient for the carbonator working at low pressure. This can be achieved in practice using a $\mathrm{CO}_{2}$ storage tank of $6 \mathrm{~m}$ in diameter and $10 \mathrm{~m}$ high, which is affordable with current technologies. For greater power a sequence of standardized tanks could be used.

\section{5. $\mathrm{Na}_{2} \mathrm{CO}_{3}$ and $\mathrm{NaHCO}_{3}$ production from trona}

This section analyses production of $\mathrm{Na}_{2} \mathrm{CO}_{3}$ and $\mathrm{NaHCO}_{3}$ from trona decomposition in a fluidized bed reactor working at $220^{\circ} \mathrm{C}$ and 1 bar using solar thermal power as heat source. A schematic layout of the process is shown in figure 4. For the temperatures needed in this application, medium temperature parabolic troughs collectors coupled with a thermal energy storage system (i.e. with pressurized water tanks), are suitable to provide the necessary energy input.

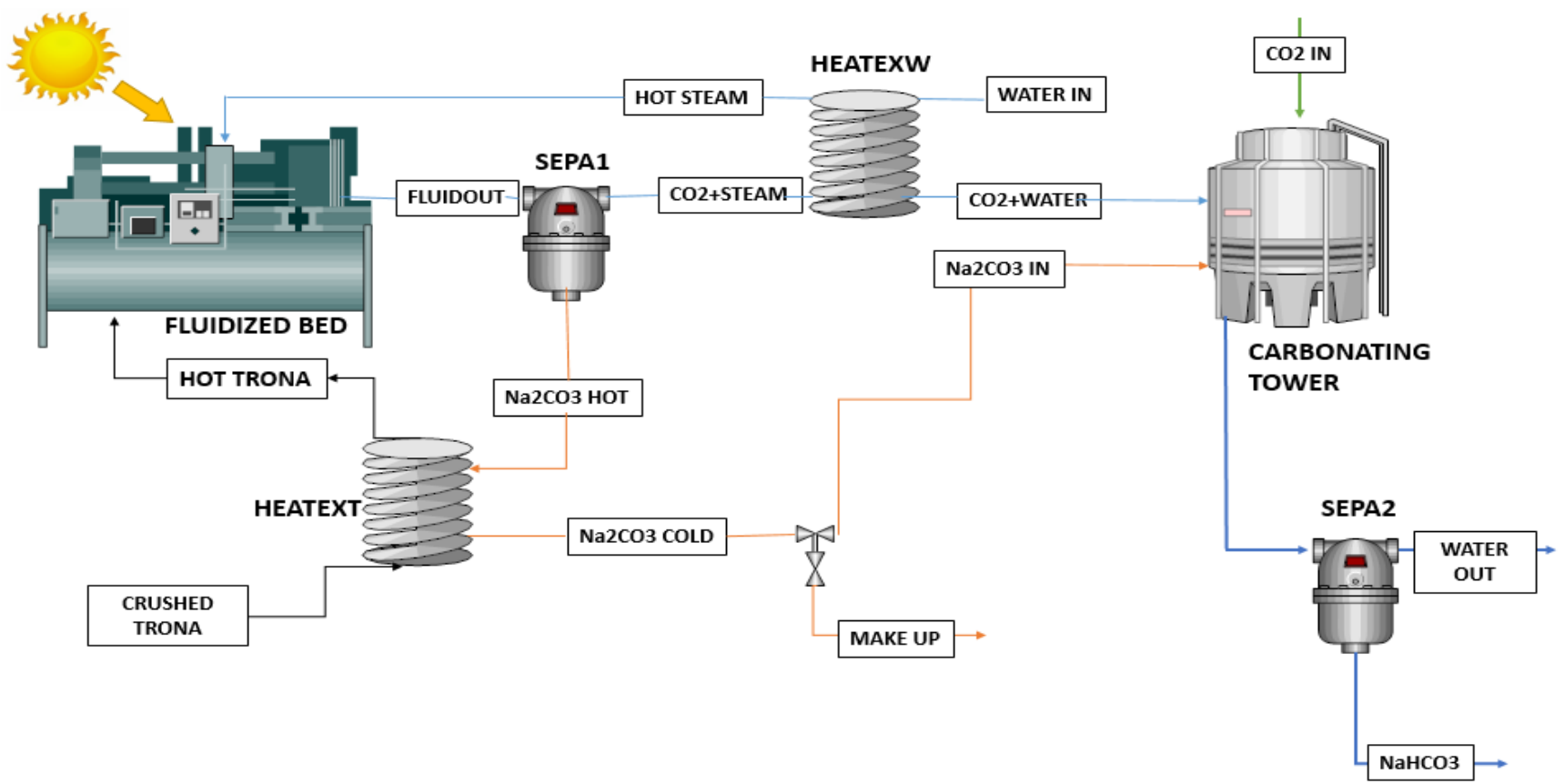

Figure 4. $\mathrm{Na}_{2} \mathrm{CO}_{3}$ and $\mathrm{NaHCO}_{3}$ production from trona assisted by solar energy.

As seen in figure 4, the stream of trona (CRUSHED TRONA), initially at $25^{\circ} \mathrm{C}$ and 1 bar, passes, before entering the fluidized bed reactor, through a solid-solid heat exchanger (HEATEXT) where it exchanges heat with the effluent $\mathrm{Na}_{2} \mathrm{CO}_{3}$ stream from the fluidized bed reactor (Na2CO3 HOT), which raises trona temperature up to $127^{\circ} \mathrm{C}$. Another heat exchanger (HEATEXW) transfers heat from the gases and water vapor stream $(\mathrm{CO} 2+\mathrm{STEAM})$ exiting the fluidized bed reactor to the water stream (WATER IN) entering the fluidized bed, which raises up its temperature to $205^{\circ} \mathrm{C}$. The total heat recovered by means of these heat exchangers amounts is $1.85 \mathrm{MW}_{\text {th }}$ as detailed in Table 6 . Flow rates of the streams entering and exiting the fluidized bed reactor are summarized in Table 7 . 
Table 6. Heat exchanged in $\mathrm{NaHCO}_{3}$ production according to Fig. 3.

\begin{tabular}{l|r|r|r|r|r}
\hline & \multicolumn{1}{|c|}{$\mathrm{MW}_{\text {th }}$} & $\mathrm{T}_{\text {incold }}\left({ }^{\circ} \mathrm{C}\right)$ & $\mathrm{T}_{\text {outhot }}\left({ }^{\circ} \mathrm{C}\right)$ & $\mathrm{T}_{\text {inhot }}\left({ }^{\circ} \mathrm{C}\right)$ & $\mathrm{T}_{\text {outcold }}\left({ }^{\circ} \mathrm{C}\right)$ \\
\hline HEATEXCT & 1.15 & 20 & 95 & 219 & 205 \\
\hline HEATEXW & 0.7 & 20 & 40 & 219 & 127 \\
\hline Total Thermal Power & 1.85 & & & & \\
\hline
\end{tabular}


Table 7. Flow rates of streams entering and exiting the fluidized bed reactor in the $\mathrm{NaHCO}_{3}$ production according to Fig. 3.

\begin{tabular}{c|c|c|c|c}
\hline & Units & TRONA & WATIN & FLUIDOUT \\
\hline TRONA & $\mathrm{kmol} / \mathrm{h}$ & 84.709 & 0 & 0 \\
\hline WATER & $\mathrm{kmol} / \mathrm{h}$ & 0.387 & 85 & 307.5 \\
\hline $\mathrm{CO}_{2}$ & $\mathrm{kmol} / \mathrm{h}$ & 0.002 & 0 & 42.5 \\
\hline $\mathrm{WEGSC}(\mathrm{S})_{\mathrm{NaHCO}}$ & $\mathrm{kmol} / \mathrm{h}$ & 0.096 & 0 & 0 \\
\hline $\mathrm{Na}_{2} \mathrm{CO}_{3}$ & $\mathrm{kmol} / \mathrm{h}$ & 0.198 & 0 & 0 \\
\hline Mole Flow & $\mathrm{kmol} / \mathrm{h}$ & 0 & 0 & 127.5 \\
\hline Temperature & $\mathrm{kmol} / \mathrm{h}$ & 146.391 & 85 & 613.5 \\
\hline Pressure & ${ }^{\circ} \mathrm{C}$ & 127 & 204 & 219 \\
\hline Vapor Fraction & $\mathrm{bar}$ & 1.01 & 1.01 & 1,01 \\
\hline Solid Fraction & & 0 & 1 & 0.733 \\
\hline Mass Density & & 1 & 0 & 0.267 \\
\hline Average Molecular Weight & & 224 & 18.015 & 43.81 \\
\hline
\end{tabular}

The heat required in the fludized bed reactor for decomposing $19.2 \mathrm{t} / \mathrm{h}$ of trona is $5.1 \mathrm{MW}_{\text {th }}$ at $220^{\circ}$ (the theoretical value to decompose $85 \mathrm{kmol} / \mathrm{h}$ of trona at $\mathrm{T}=25^{\circ} \mathrm{C}$ is $3.15 \mathrm{MW}_{\text {th }}$ from the reaction enthalpy $\Delta H_{298 \mathrm{~K}}=133.9 \frac{\mathrm{KJ}}{\mathrm{mol}}$ [11][25]). Such amount of heat, which can be provided by medium temperature solar thermal power, warrants the production of $13.55 \mathrm{t} / \mathrm{h}$ of $\mathrm{Na}_{2} \mathrm{CO}_{3}\left(\mathrm{Na}_{2} \mathrm{CO}_{3} \mathrm{COLD}\right.$ in Fig. 6) plus $1.85 \mathrm{ton} / \mathrm{h}$ of $\mathrm{CO}_{2}$ and $4 \mathrm{t} / \mathrm{h}$ of water $\left(\mathrm{CO}_{2}+\mathrm{STEAM}\right)$ of which $300 \mathrm{~kg} / \mathrm{h}$ are used as makeup in the dry carbonate process for $\mathrm{CO}_{2}$ capture (MAKE UP) while the rest is sent to a carbonating tower $\left(\mathrm{Na}_{2} \mathrm{CO}_{3} \mathrm{IN}\right)$ to produce sodium bicarbonate $\left(\mathrm{NAHCO}_{3}\right)$ using a $3.75 \mathrm{t} / \mathrm{h}$ stream of pure $\mathrm{CO}_{2}$ from the carbon capture system $\left(\mathrm{CO}_{2} \mathrm{IN}\right)$ and the $\mathrm{CO}_{2}$ and water streams released from the fluidized bed reactor $\left(\mathrm{CO}_{2}+\mathrm{STEAM}\right)$. From the $\mathrm{Na}_{2} \mathrm{CO}_{3}$ carbonation reaction (Eq. 2) it turns out that $20.75 \mathrm{t} / \mathrm{h}$ of $\mathrm{NaHCO}_{3}$ are produced at a total flow rate of about $9.5 \mathrm{~m}^{3} / \mathrm{h}$. In this way, a commercial chemical product is produced using captured $\mathrm{CO}_{2}$ from the power plant with a higher economic value than the raw mineral.

\section{Overall system efficiency}

The CFPP efficiency is reduced due to the heat employed for the production of $\mathrm{NaHCO}_{3}$, albeit an economic revenue is obtained. Considering the $5.1 \mathrm{MW}_{\text {th }}$ needed in the fluidized bed reactor, the total heat requirement is $61.2 \mathrm{MW}_{\text {th }}$ (Table 8).

Table 8. Heat requirement in different components for the production of $\mathrm{NaHCO}_{3}$.

\begin{tabular}{l|c|c}
\hline & $\mathrm{T}\left({ }^{\circ} \mathrm{C}\right)$ & Thermal Power consumption \\
\hline CFFP & 850 & $44.7 \mathrm{MW}_{\text {th }}$ \\
\hline Regenerator & 200 & $11.4 \mathrm{MW}_{\text {th }}$ \\
\hline Fluidized bed reactor & 220 & $5.1 \mathrm{MW}_{\mathrm{el}}$ \\
\hline Total heat requirement & & $61.2 \mathrm{MW}_{\text {th }}$ \\
\hline
\end{tabular}

26 By avoiding storage of part of the $\mathrm{CO}_{2}$ captured for half a day (considering 12 hours of daylight) the total power consumption for compression decreases to $0.879 \mathrm{MW}_{\mathrm{el}}$ (Table 9). 
Table 9. Compression power for $\mathrm{NaHCO}_{3}$ production.

\begin{tabular}{l|r}
\hline Component & $\mathrm{W}_{\text {comp }}\left(\mathrm{MW}_{\mathrm{el}}\right)$ \\
\hline Compressor 1 ( 4.2 bar ) & 0.295 \\
\hline Compressor 2 ( 17.5 bar ) & 0.289 \\
\hline Compressor 3 ( 75 bar ) & 0.295 \\
\hline Total $\mathrm{W}_{\text {comp }}$ ( from 1 to 75 bar ) & 0.879 \\
\hline
\end{tabular}

For the reference CFPP with integrated $\mathrm{CO}_{2}$ capture, and considering a power consumption of 0.247 $\mathrm{MW}_{\mathrm{el}}$ for solids conveying and $0.3 \mathrm{MW}$ for centrifuge stages, the global efficiency penalty is -10.2 $\%$ over the baseline plant and the mean global electricity production is decreased by $-9 \%$. It results in a net efficiency of the global plant of $23 \%$ :

$$
\begin{gathered}
\eta_{N E T}=\frac{13,123 M W_{e l} \cdot 12 h+13,574 M W_{e l} \cdot 12 h}{56,1 M W_{t h} \cdot 12 h+61,2 M W_{t h} \cdot 12 h}=0.23 \\
\eta_{N E T_{e l}}=\frac{13,123 M W_{e l} \cdot 12 h+13,574 M W_{e l} \cdot 12 h}{15 M W_{e l} \cdot 24 h}=0.89
\end{gathered}
$$

If the low temperature heat required in the calciner and regenerator is provided from renewables a near zero emissions system is obtained. By using solar energy for heating, that penalty on the original plant economic efficiency amounts to only $3 \%$, which is associated to the parasitic power consumption of the post-combustion system.

\section{Economic Analysis}

For the economic analysis of the integrated process different scenarios are defined to analyze the competitiveness of the technology[45]. These scenarios are defined in terms of:

- $\mathrm{NaHCO}_{3}$ production, to take into account the variability of demand in the market.

- Variation of trona costs, taking into account trona cost variability.

- Variation of $\mathrm{NaHCO}_{3}$ sale prices on the market.

- Different plant installation costs. To consider uncertainty in equipment cost evolution a maximum deviation has been considered for the scenario. The variation range was taken as $\pm 9 \%$ of the average installation price.

Attending to these criteria three scenarios are considered:

Scenario P (Pessimistic Scenario): it takes into consideration a combination of diverse factors such as the highest penalty in electricity generation (it has been taken as the maximum error in estimating parasitic electricity losses), the highest plant installation costs, the highest cost of trona, and lowest sale price of $\mathrm{NaHCO}_{3}$ in the market.

4 Scenario BE (Best Estimation Scenario): In this scenario the values derived from the simulation above described were used to define the efficiency of the system. It considers a capital cost of $3 \mathrm{M} €$ for the CCS technology [25]. This scenario uses current values of trona cost and $\mathrm{NaHCO}_{3}$ sale price in the market.

Scenario O (Optimistic Scenario): this optimistic scenario implies minor trona and plant installation costs.

Considering that the price of trona is in the range 80-120 \$/ton [46] and that the sale price of $\mathrm{NaHCO}_{3}$ is around 200-240 \$/ton, the economic profit for production of $\mathrm{NaHCO}_{3}$ can be calculated as: 
4 Here $\mathrm{E}_{\mathrm{P}}$ is the economic profit derived from $\mathrm{NaHCO}_{3}$ production, $\mathrm{p}_{\mathrm{NaHCO}}$ and $\mathrm{p}_{\text {trona }}$ are the selling price of $\mathrm{NaHCO}_{3}$ and purchase price of trona, respectively, and $\dot{m}_{\mathrm{NaHCO}}$ and $\dot{m}_{\text {trona }}$ are the $\mathrm{NaHCO}_{3}$ and trona mass flow rates, respectively. Table 10 shows the prices calculated for the different scenarios considered.

Table 10. Different prices for different scenarios.

\begin{tabular}{c|c|c|c|c}
\hline & Units & Scen. $\mathrm{P}$ & Scen. BE & Scen. O \\
\hline $\mathrm{p}_{\text {trona }}$ & $€ /$ ton & 120 & 100 & 80 \\
\hline $\mathrm{p}_{\text {NaHCO3 }}$ & $€ /$ ton & 200 & 220 & 240 \\
\hline$\Delta_{\text {Gain }}$ & $€ /$ ton & 80 & 120 & 160 \\
\hline $\mathrm{E}_{\text {GAIN }}$ & $€ /$ day & 22000 & 32000 & 44000 \\
\hline
\end{tabular}

The investment cost of the solar technology is in the range 2.5-3.5 $\mathrm{M} € / \mathrm{MW}_{\text {th }}$ for a parabolic trough collectors plant with thermal energy storage [47] whereas the fluidized bed reactor cost is about 0.25 $\mathrm{M} / \mathrm{MW}_{\text {th }}$ with an error margin of $+/-25 \%$ [48]. Operation \& maintenance costs are taken as $10 \%$ of the baseline cost. The costs of other components of the solar field are estimated as $15 \%$ of the solar capital expenditures. Table 11 summarizes the investment costs of the plant for the different scenarios considered and according to different prices of the solar thermal technology. The total investment cost (ЕТOT) takes into account the cost of solar technology (ESOLAR), the cost of the fluidized bed reactor used for trona conversion (EFLID), the cost of reactors for dry carbonate process ( $\left.E_{D R Y}\right)$ and

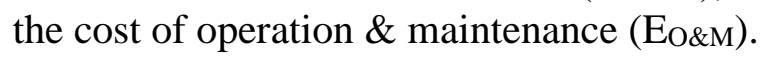

Table 11: Total investment cost: $\mathrm{NaHCO}_{3}$ production + Solar Thermal.

\begin{tabular}{|c|c|c|c|c|}
\hline \multicolumn{5}{|c|}{ Solar Thermal 2.5 M€/MW } \\
\hline & Units & Scen. P & Scen. BE & Scen. O \\
\hline ESOLAR (FLUID+DECARB) & $\mathrm{M} €$ & 42.5 & 41.25 & 40.5 \\
\hline EDRY & $M €$ & 4 & 3 & 2 \\
\hline EFLUID & $M €$ & 1.9 & 1.5 & 1.15 \\
\hline Eo\&M & $M €$ & 4.84 & 4.58 & 4.37 \\
\hline $\mathrm{E}_{\text {TOT }}$ & $M €$ & 51.34 & 48.83 & 46.87 \\
\hline & Units & Scen. P & Scen. BE & Scen. $\mathrm{O}$ \\
\hline \multicolumn{5}{|c|}{ Solar Thermal $3 \mathrm{M} € / \mathrm{MW}$} \\
\hline ESOLAR (FLUID+DECARB) & $\mathrm{M} €$ & 51 & 49.5 & 48.6 \\
\hline EDRY & $M €$ & 4 & 3 & 2 \\
\hline EFLUID & $M €$ & 1.9 & 1.5 & 1.15 \\
\hline EO\&M & $M €$ & 5.69 & 5.4 & 5.18 \\
\hline ETOT & $M €$ & 60.69 & 57.9 & 55.78 \\
\hline \multicolumn{5}{|c|}{ Solar Thermal 3.5 M€/MW } \\
\hline & Units & Scen. P & Scen. BE & Scen. $\mathrm{O}$ \\
\hline ESOLAR (FLUID+DECARB) & $\mathrm{M} €$ & 59.5 & 57.75 & 56.7 \\
\hline EDRY & $M €$ & 4 & 3 & 2 \\
\hline EFLUID & $M €$ & 1.9 & 1.5 & 1.15 \\
\hline EO\&M & $M €$ & 6.54 & 6.23 & 5.98 \\
\hline ETOT & $M €$ & 70.04 & 66.98 & 64.68 \\
\hline
\end{tabular}


solar technology cost. Table 12 shows the total investment costs and estimated annual profit for

Table 12: Total Investment costs and yearly revenue for scenarios of analysis.

\begin{tabular}{c|c|c|c}
\hline TOTAL INVESTMENT & SCENARIO P & SCENARIO BE & SCENARIO O \\
\hline SOLAR THERMAL COST 2.5 M€/MW & $51.34 \mathrm{M} €$ & $48.83 \mathrm{M} €$ & $46.87 \mathrm{M} €$ \\
\hline SOLAR THERMAL COST 3 M€/MW & $60.69 \mathrm{M} €$ & $57.90 \mathrm{M} €$ & $55.78 \mathrm{M} €$ \\
\hline SOLAR THERMAL COST 3.5 M€/MW & $70.04 \mathrm{M} €$ & $66.98 \mathrm{M} €$ & $64.69 \mathrm{M} €$ \\
\hline ANNUAL ECONOMIC PROFIT & $8.08 \mathrm{M} €$ & $11.58 \mathrm{M} €$ & $15.08 \mathrm{M} €$ \\
\hline
\end{tabular}

Using these data, CCU investment's simple payback period (SPB) can be evaluated. SPB is the time for recovering the initial investment, which is given by:

$$
S P B=\frac{E_{T O T}}{E_{P}}
$$

Figure 5 shows estimated SPB values for the different scenarios as a function of solar thermal technology investment cost and for a constant production of 7470 ton/month of $\mathrm{NaHCO}_{3}$.

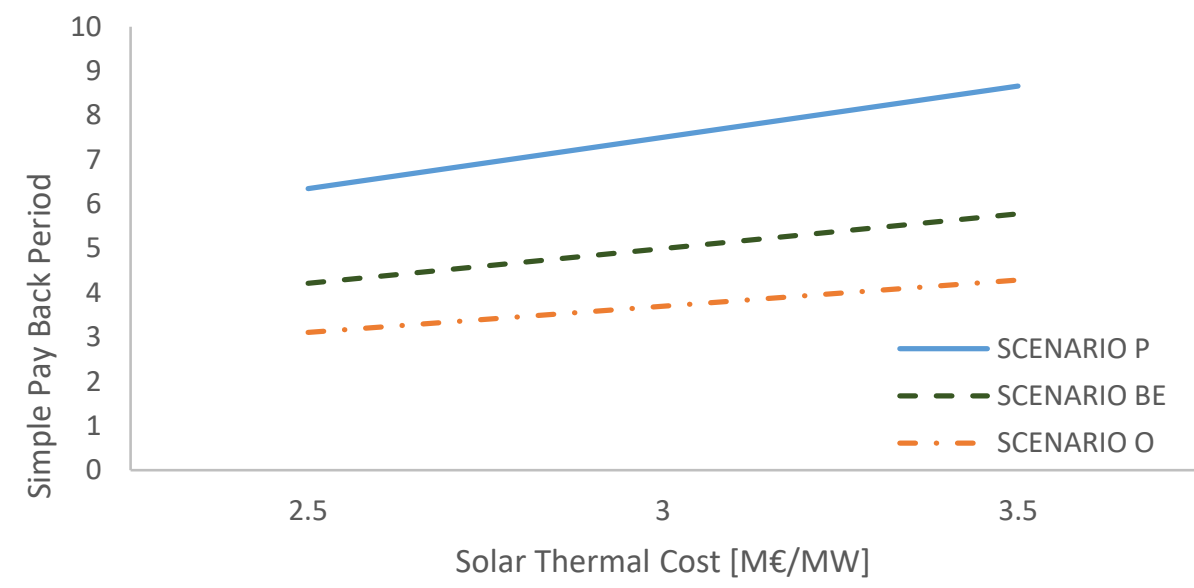

Figure 5. SPB as a function of solar thermal technology costs for the different scenarios analyzed.

Figure 5 shows that relatively short SPB periods are obtained. In the worst case (Pessimistic Scenario) the SPB period is equal to 8.7 years while in the best case it amounts to only 3 years (Optimistic Scenario). These values suggest a high interest of the integration proposed in this paper, combining the dry carbonate $\mathrm{CO}_{2}$ capture and sodium bicarbonate production using trona as raw material where it is available. However, the SPB does not address the time value of money, inflation, project lifetime or operation. For this reason, it is important to evaluate internal rate of return (IRR), which can be evaluated from the definition of net present value (NPV). NPV is the sum of the discounted cash flow minus the total investment cost:

$$
N P V=\sum_{k=0}^{N} \frac{E_{N E T, G A I N, \text { year }}}{(I R+1)^{k}}-E_{T O T}
$$

where $k$ represents the year number, $N$ is the total number of years, and $I R$ is the discount rate. Assuming different values of the discount rate NPV value is calculated for the different scenarios and as function of the solar thermal technology cost. Figures 6,7 and 8 show the NPV calculated curves 
years. It can be seen how consistent revenues from the sale of $\mathrm{NaHCO}_{3}$ are obtained for realistic

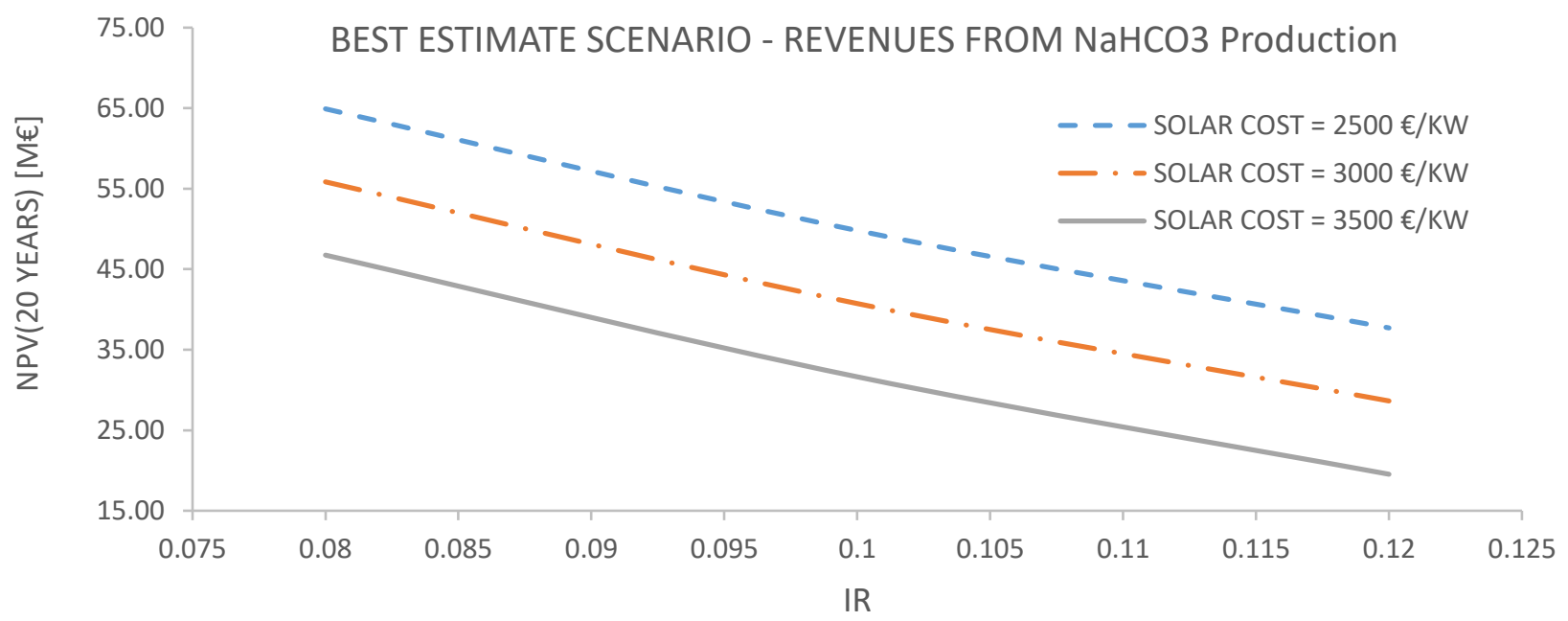

4

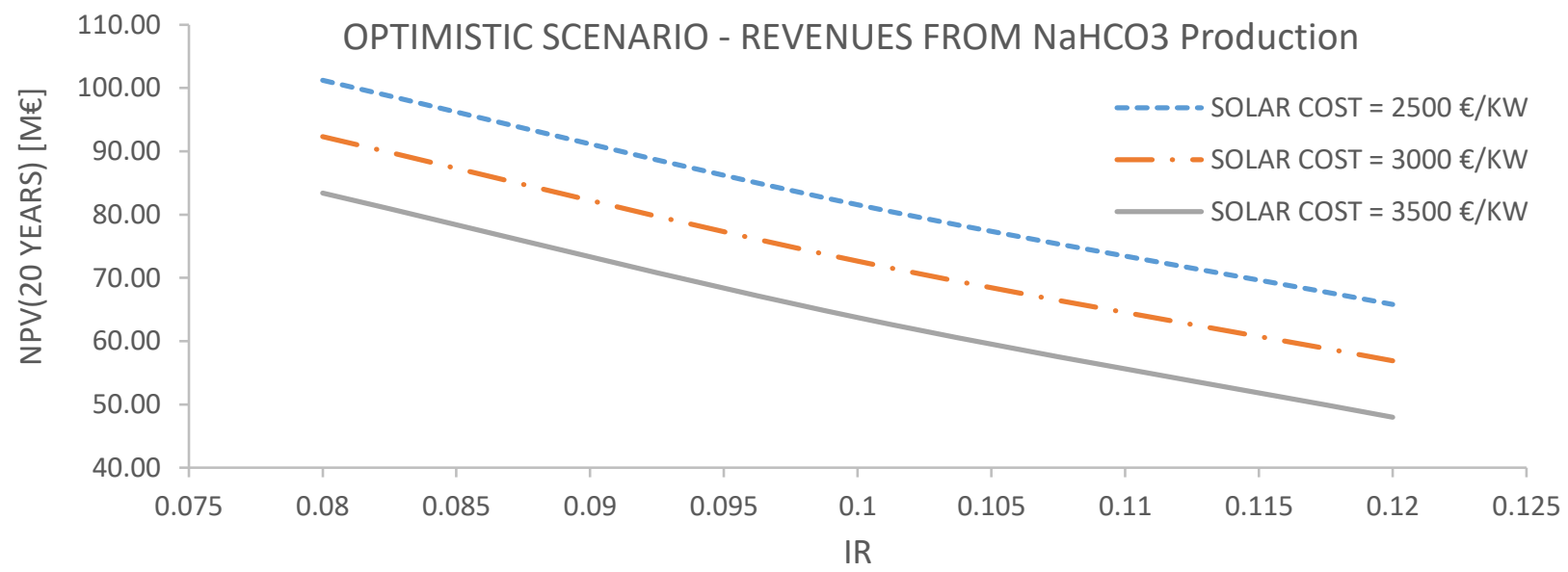

Figure 7. Optimistic Scenario: NPV in 20 years as function of internal rate value and solar thermal

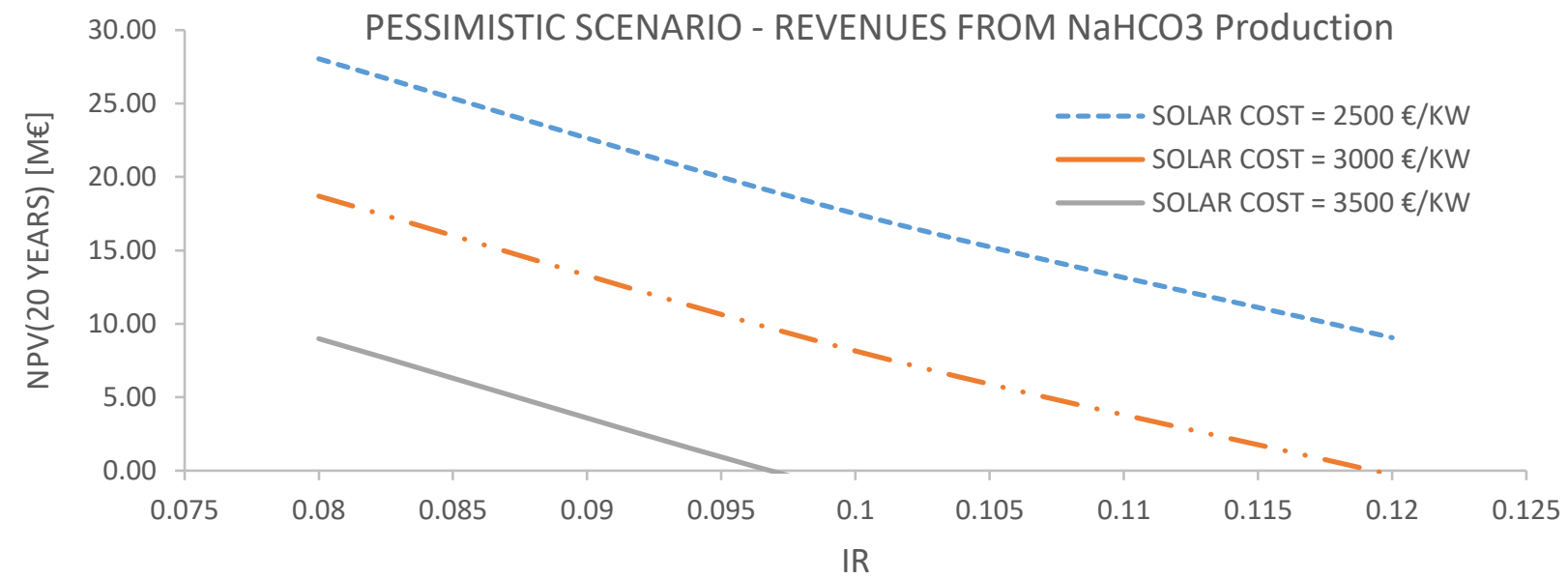

Figure 8. Pessimistic Scenario: NPV in 20 years as function of internal rate value and solar thermal technology costs. 
The internal rate of return (IRR) is the discount rate at which NPV is equal to zero or, in other words, the rate at which an investment breaks even. It can be seen in Figures 6 and 7 that high values of internal rate of return (IRR>0.12) are obtained, while for the pessimistic scenario the value of $\mathrm{IRR}=0.12$ is reached for a solar thermal cost of $3 \mathrm{M} € / \mathrm{MW}$. Considering the life of the plant equal to 20 years the investment would be always of interest having current ordinary IR values of $0.08-0.1$. Moreover, considering an IR of 0.1 higher values of NPV are obtained. Also considering a solar technology cost of $3.5 \mathrm{M} € / \mathrm{MW}_{\text {th }}$, it results a NPV value of $31.6 \mathrm{M} €$ with an investment cost of 67 M€ referred to the best estimate scenario. These values have been obtained assuming a constant production for sale of $\mathrm{NaHCO}_{3}$. Figure 9 shows NPV values as a function of the produced $\mathrm{NaHCO}_{3}$ for the Best Estimate Scenario and using a fixed discount rate value (IR=0.1).

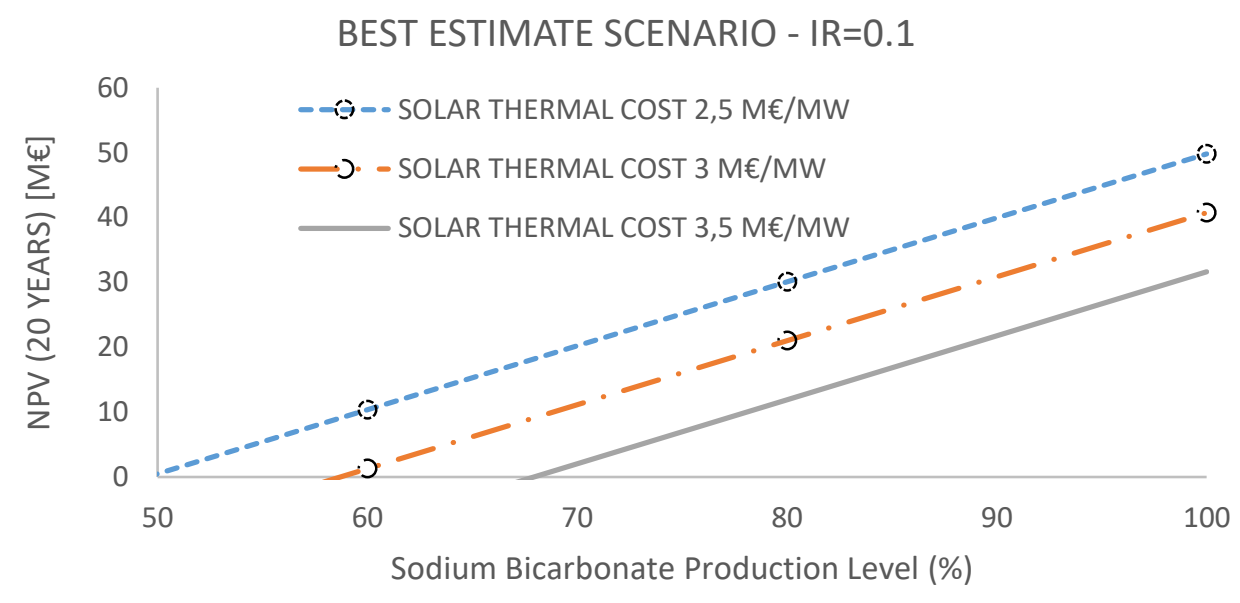

Figure 9. NPV in 20 years as function of $\mathrm{NaHCO}_{3}$ production and solar technology costs for a fixed discount rate $\mathrm{IR}=0.1$.

As shown in Figs. 8 a minimum production of sodium bicarbonate per month is needed to ensure the return of the investment cost $(\mathrm{NPV}=0)$. In the worst case, which comprises the maximum cost of solar thermal technology, at least 5080 ton/month $(68 \%)$ of sodium bicarbonate must be produced to cover the investment with a discount rate of $I R=0.1$. On the other extreme, for the best case (a minimum cost of solar thermal technology), a production of 3585 ton/month would be needed.

\section{Carbon taxes}

The previous analysis does not include any benefit in terms of taxes due to avoided $\mathrm{CO}_{2}$ emissions. However, this technology would dramatically reduce emissions of the plant, which would result in additional cost savings that would increase the interest of the investment. Table 13 summarizes the data used for calculating the costs according to the different scenarios for a total amount of 108.9 kton/year avoided $\mathrm{CO}_{2}$ emissions using the dry carbonation system.

Table 13: $\mathrm{CO}_{2}$ emission data for different scenarios.

\begin{tabular}{c|c|c|c|c}
\hline & $\begin{array}{c}\text { DEFE } \\
\text { PLANT }\end{array}$ & $\begin{array}{c}\text { DRY } \\
\text { CARBONATE } \\
(\mathrm{P})\end{array}$ & $\begin{array}{c}\text { DRY } \\
\text { CARBONATE } \\
(\mathrm{BE})\end{array}$ & $\begin{array}{c}\text { DRY } \\
\text { CARBONATE } \\
\text { (O) }\end{array}$ \\
\hline Power (MWel) & 15 & 15 & 15 & 15 \\
\hline CCS Power consumption (MWel) & & 2.5 & 1.6 & 1.5 \\
\hline Regenerator Heat requirement (MWth) & & 11.9 & 11.4 & 11.1 \\
\hline Net power (MWel) & 15 & 12.5 & 13.35 & 13.5 \\
\hline $\mathrm{CO}_{2}$ Emissions (tons/hr) & 13.5 & 1.07 & 1.07 & 1.07 \\
\hline $\mathrm{CO}_{2}$ Emissions (kmol/hr) & 308 & 24.32 & 24.32 & 24.32 \\
\hline $\mathrm{CO}_{2}$ Avoided Emissions (kton/year) & & 108.9 & 108.9 & 108.9 \\
\hline $\mathrm{CO}_{2}$ Emissions (tons/ MWhel) & 0.9 & 0.085 & 0.08 & 0.079 \\
\hline
\end{tabular}


2 The carbon tax is assumed as constant during the next years in the worst scenario (Scenario P) while is supposed that will increase in the future years for the optimistic scenario (Scenario O). Average values of carbon tax are taken into account for the analysis. The gain from avoided $\mathrm{CO}_{2}$ emission is given by:

$$
E_{C O 2, A V O I D E D}=\left(\operatorname{ton}_{C O 2, r e f}-\operatorname{ton}_{C O 2, C C S}\right) \cdot c_{C O 2}
$$

Where $\mathrm{c}_{\mathrm{CO} 2}$ is the carbon tax expressed in $€ /$ ton ${ }_{\mathrm{CO} 2}$. The economic benefits derived from $\mathrm{CO}_{2}$ avoided emissions under the different carbon tax scenarios are shown in Table 14.

Table 14: Revenues due to $\mathrm{CO}_{2}$ emission reduction for different scenarios (20 years).

\begin{tabular}{c|c|c|c}
\hline & SCENARIO P & SCENARIO BE & SCENARIO O \\
\hline Carbon Tax & $10 € /$ ton $_{\text {co2 }}$ & $18 € /$ ton $_{\text {CO2 }}$ & $25 € /$ ton $_{\text {co2 }}$ \\
\hline Yearly Economic Gain & $1.09 \mathrm{M} € /$ year & $1.96 \mathrm{M} € /$ year & $2.72 \mathrm{M} € /$ year \\
\hline $\mathrm{IR}=0.08$ & $10.89 \mathrm{M} €$ & $19.60 \mathrm{M} €$ & $29.00 \mathrm{M} €$ \\
\hline $\mathrm{IR}=0.1$ & $8.72 \mathrm{M} €$ & $15.70 \mathrm{M} €$ & $23.18 \mathrm{M} €$ \\
\hline $\mathrm{IR}=0.12$ & $7.71 \mathrm{M} €$ & $13.88 \mathrm{M} €$ & $20.33 \mathrm{M} €$ \\
\hline
\end{tabular}

Figures 10, 11 and 12 show the economic impact due to $\mathrm{CO}_{2}$ avoided emission for different scenarios and different values of IR.

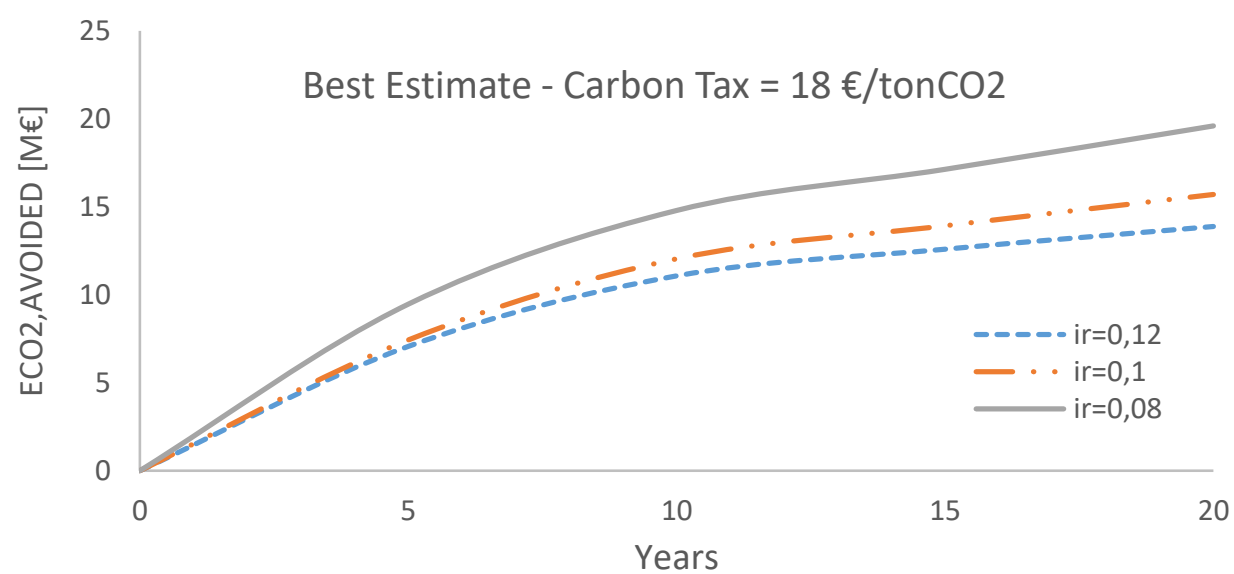

Figure 10. Best Estimated Scenario: Economic Gain due to $\mathrm{CO}_{2}$ avoided emissions.

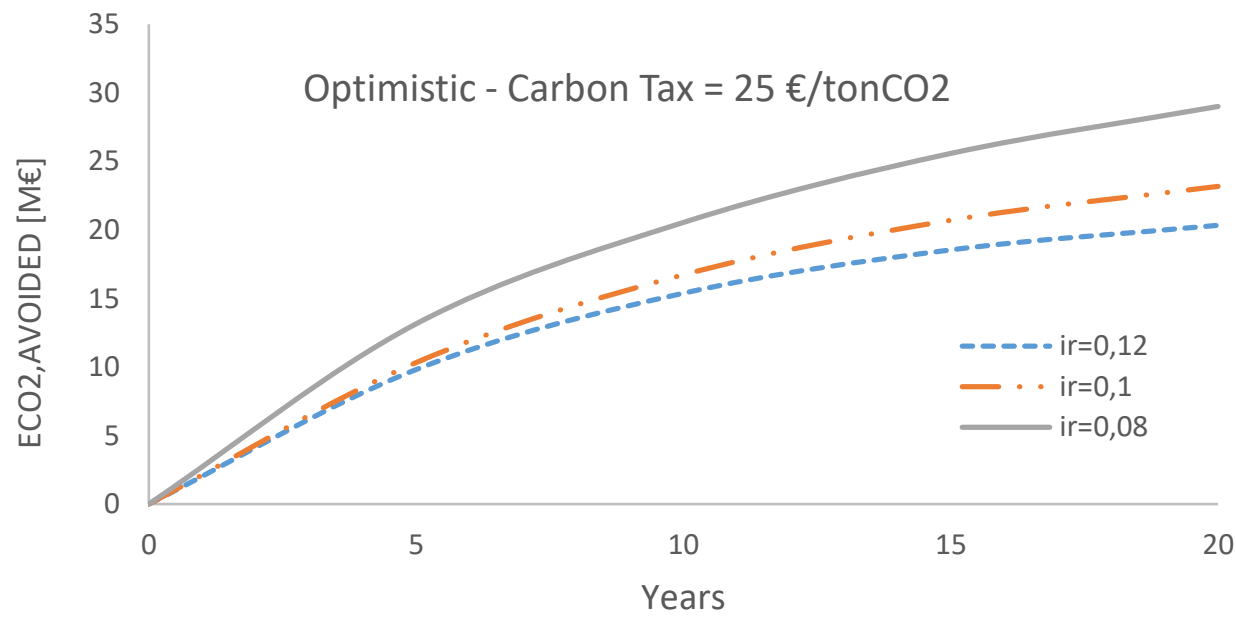

Figure 11. Optimistic Scenario: Economic Gain due to $\mathrm{CO}_{2}$ avoided emissions. 


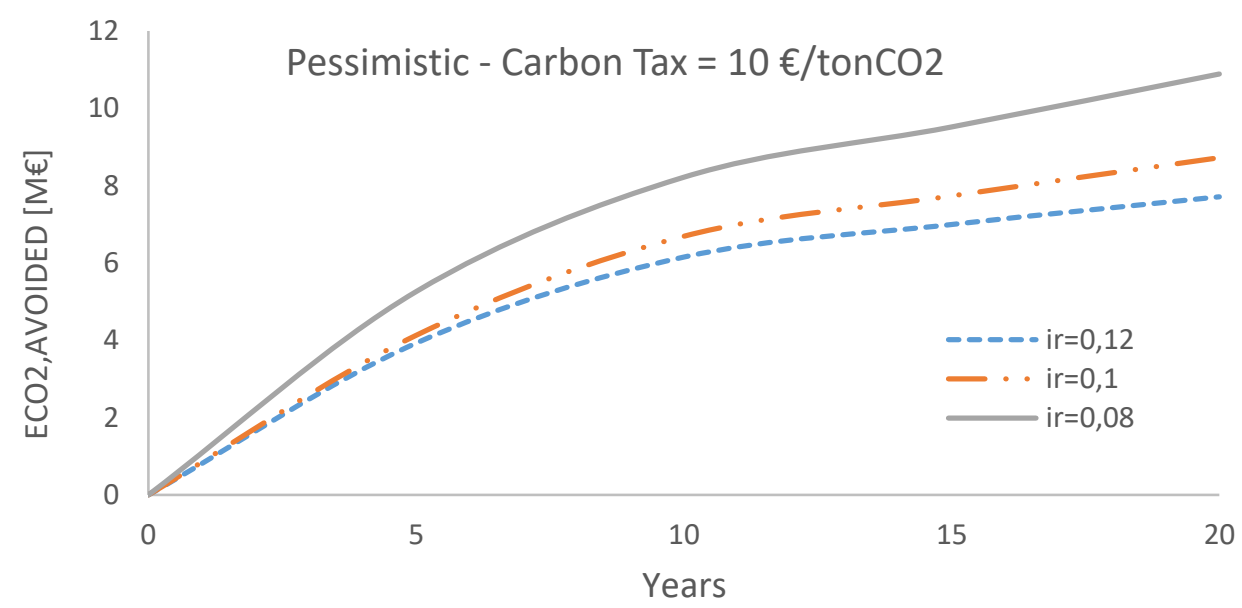

Figure 12. Pessimistic Scenario: Economic Gain due to $\mathrm{CO}_{2}$ avoided emissions.

4

Under carbon taxes scenarios the NPV of the CCU investment can be recalculated adding cost savings due to carbon taxes. Results, considering a production level of 7470 ton/month, are shown in Table 15 , where only in the worst case (Pessimistic Scenario, maximum cost of solar thermal technology and $I R=0.12$ ) NPV negative values are obtained. Considering the Best Estimate Scenario, with a mean cost of solar technology (3M€/MW), and IR 0.1, the NPV goes up to 56.4 M€ in 20 years.

Table 15:NPV(20 years) values including savings from $\mathrm{CO}_{2}$ emission reduction.

\begin{tabular}{c|c|c|c|c}
\hline IR & SOLAR COST(ME/MW) & SCENARIO P & SCENARIO BE & SCENARIO O \\
\hline \multirow{3}{*}{0,08} & 2.5 & 38.93 & 84.51 & 130.24 \\
\cline { 2 - 5 } & 3 & 29.58 & 75.44 & 121.33 \\
\cline { 2 - 5 } & 3.5 & 19.87 & 66.34 & 112.41 \\
\hline \multirow{3}{*}{0,1} & 2.5 & 26.22 & 65.50 & 104.73 \\
\cline { 2 - 5 } & 3 & 16.87 & 56.43 & 95.82 \\
\hline \multirow{3}{*}{0,12} & 3.5 & 7.6 & 47.33 & 86.90 \\
\cline { 2 - 5 } & 2.5 & 16.77 & 51.58 & 86.14 \\
\cline { 2 - 5 } & 3 & 7.42 & 42.51 & 77.23 \\
\hline
\end{tabular}

\section{Sodium bicarbonate prices}

In figures 13 to $15 \mathrm{NPV}$ data are plotted for different investment costs as a function of the sale price of $\mathrm{NaHCO}_{3}$ and trona in the market and taking into account a variable production (from $50 \%$ to $100 \%$ ). A fixed $\mathrm{IR}=0.1$ is considered in these analyses. 


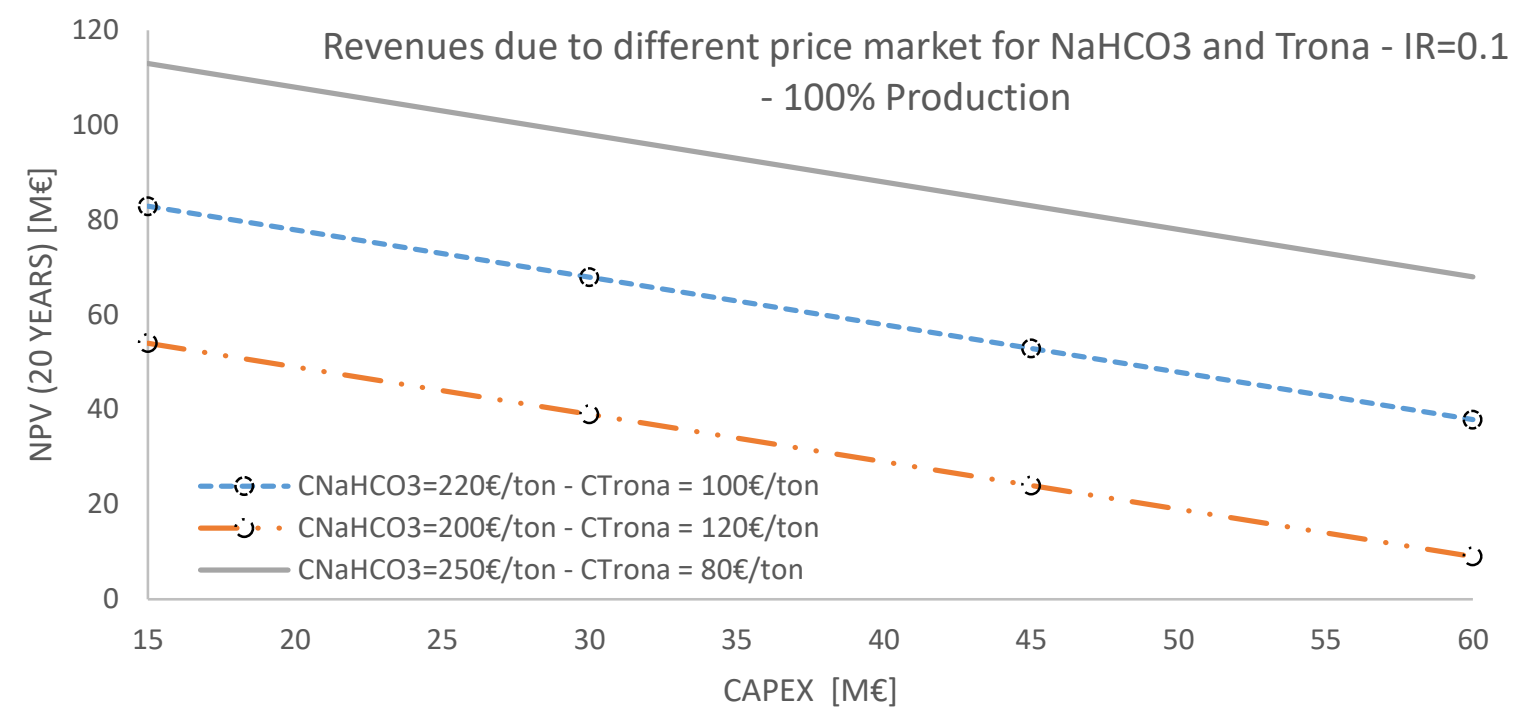

Figure 13. NPV in 20 years as function of investment costs and $\mathrm{NaHCO}_{3}$ price with $100 \%$ of $\mathrm{NaHCO}_{3}$ total production.

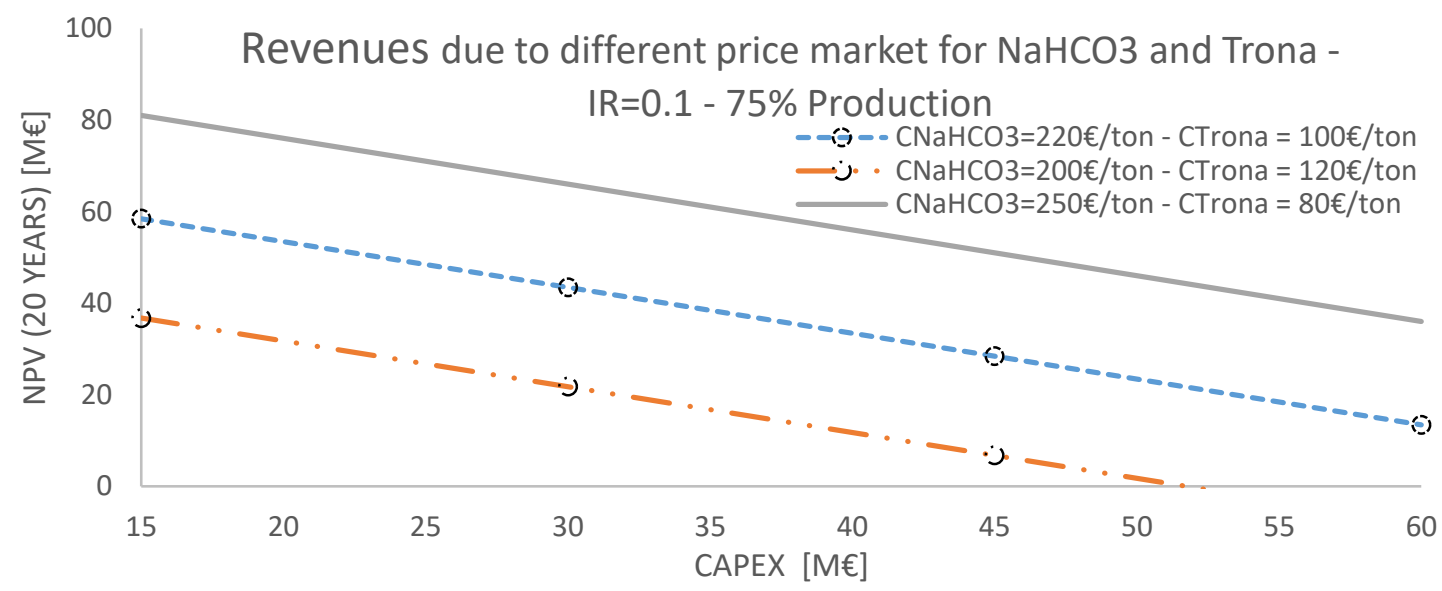

Figure 14. NPV in 20 years as function of investment costs and $\mathrm{NaHCO}_{3}$ price with $75 \%$ of $\mathrm{NaHCO}_{3}$ total production.

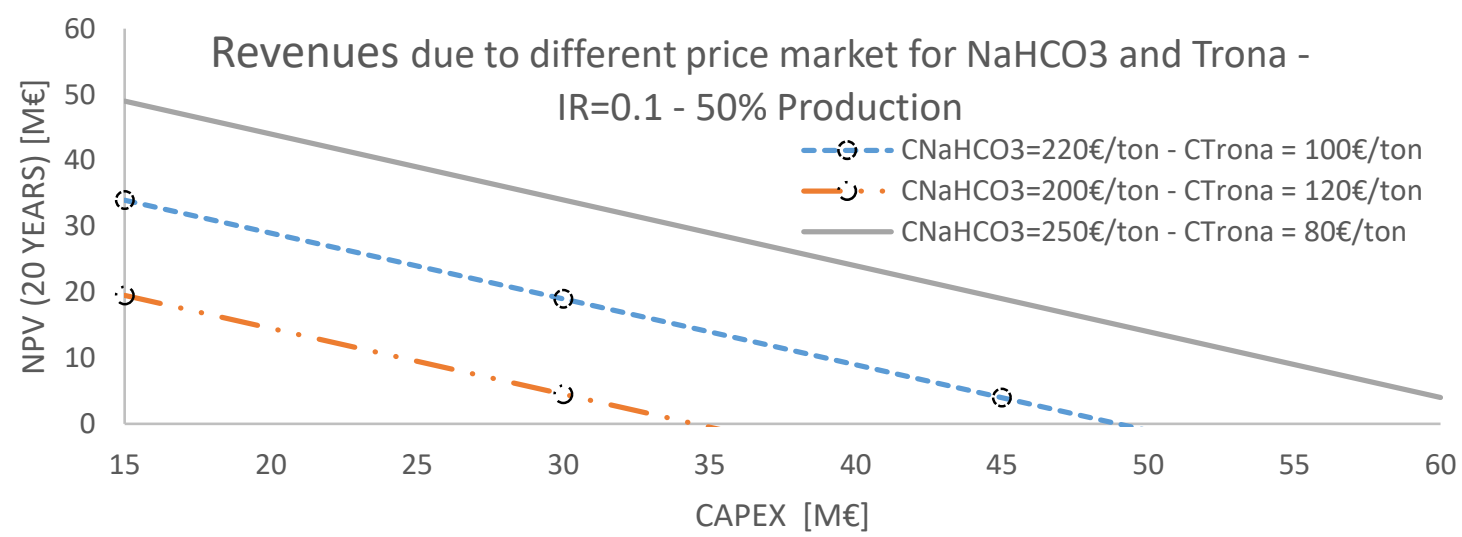

Figure 15. NPV in 20 years as function of investment costs and $\mathrm{NaHCO}_{3}$ price with $50 \%$ of $\mathrm{NaHCO}_{3}$ total production.

Figures 13 to 15 , give a map of CCU investment profitability as function of sodium bicarbonate price and demand (linked to production). In this sense, production capacity depends on solar energy input. For periods without solar resource availability thermal storage can be used to assure $\mathrm{CO}_{2}$ capture and 
sodium bicarbonate production. The use of biomass would maintain the near zero emissions condition and could support capture when the stored thermal energy is not able to deal with it. Another important factor to consider is how $\mathrm{NaHCO}_{3}$ demand could vary on the market. For example, if the demand raises constantly, production could be maintained at the maximum capacity but it must be kept in mind that a massive introduction of the concept proposed in this paper necessarily would affect to the sodium bicarbonate production price by reducing it. In any case this is not pretended to be a global solution but one for locations with trona availability. From an economic perspective, the market is expected to grow at $4 \%$ per year in the next few years and will reach 4.2 million tonnes by 2018 driven mainly by the Asia region and China in particular. The European market is expecte to grow a $2 \%$ per year [49]. A plant of $15 \mathrm{MW}_{\text {el }}$ could produce about $40 \mathrm{kton}$ of $\mathrm{NaHCO}_{3}$. Thus, such production would have a relatively low impact at the global scale although the local sale impact could be significant. Independently of sodium bicarbonate sale, the $\mathrm{CC}$ system results in a permanent $\mathrm{CO}_{2}$ fixing in the sodium bicarbonate and its integration with renewables (solar, biomass) drives to a near $\mathrm{CO}_{2}$ emissions technology. In addition, $\mathrm{CO}_{2}$ avoided emission reduction has an economic return where carbon taxes are applied.

\section{Conclusions}

In this work a novel Carbon Capture and Utilization concept is presented based on the integration of a $\mathrm{CO}_{2}$ post-combustion system using the dry carbonate process assisted by renewables for sodium bicarbonate production. Results suggest a potentially high interest of the integration. Main aspects of the concept are:

- Sodium bicarbonate is produced for sale and for make-up in the dry carbonate $\mathrm{CO}_{2}$ capture process.

- An abundant, non-toxic and cheap raw material (trona) is used.

- When coupled with renewables for heating, biomass or medium temperature solar thermal, technology to regenerate the sorbent and calcination of trona, the global system results in a near to zero $\mathrm{CO}_{2}$ emissions technology with a reduced penalty in power generation.

- $\mathrm{NaHCO}_{3}$ production could allow permanent $\mathrm{CO}_{2}$ storage.

- As concept application it has been applied to the flue gases stream equivalent to a small coal power plant of $15 \mathrm{MW}$, or for a fraction of flue gases of a bigger coal power plant.

- Energy analysis show a minor penalty in power consumption $(<3 \%)$.

- According to the economic analysis with different Scenarios the Simple Pay Back time (SPB) for the integrated solution has very short periods (8.7 years in the worst case and 3 years in the best case) remarking the interest of the concept.

- The preliminary study shows an interesting potential for advancing in this technology in further studies (kinetics, sorbent deactivation, optimization of integration, equipment design, byproducts usage, etc...).

- When heat supply is based on solar, the proposed technology requires heat storage or support from other sources as biomass to work continuously. Various storage technologies (phase change liquid, thermal oils, molten salt) are already present on the market and a thorough study on the relative volumes of accumulation and on the exploitation of renewable sources is required to define in the best way the effective feasibility of this system. 
Nomenclature

\section{Components}

CARBONATING TOWER $\mathrm{CO}_{2}$ capture and $\mathrm{NaHCO}_{3}$ production reactor

CARBONATOR

$\mathrm{CO}_{2}$ capture reactor

COAL FIRED PLANT

Coal fired plant for electricity production

COMP1

Compressor $\mathrm{CO}_{2}$ (1-10 bar)

COMP2

Compressor $\mathrm{CO}_{2}$ (10-25 bar)

COMP3

Compressor $\mathrm{CO}_{2}$ (25-75 bar)

COOL

FLUIDIZED BED

HEATEX1

$\mathrm{CO}_{2}\left(20^{\circ} \mathrm{C}\right)$ intercooler

Fluidized bed reactor

$\mathrm{H}_{2} \mathrm{O}$-flue gas heat exchanger

HEATEXCH

HEATEXT

$\mathrm{NaHCO}_{3}-\mathrm{Na}_{2} \mathrm{CO}_{3}$

HEATEXW

Trona - $\mathrm{Na}_{2} \mathrm{CO}_{3}$ heat exchanger

$\mathrm{H}_{2} \mathrm{O}$ - steam $+\mathrm{CO}_{2}$ heat exchanger

INTERC1

$\mathrm{CO}_{2}\left(20^{\circ} \mathrm{C}\right)$ intercooler

INTERC2

$\mathrm{CO}_{2}\left(20^{\circ} \mathrm{C}\right)$ intercooler

INTERC3

REGENARATOR

SEPA1

$\mathrm{CO}_{2}\left(20^{\circ} \mathrm{C}\right)$ intercooler

Sorbent regenerator

Solid-gas separator

SEPA2

Solid-gas separator

\section{Streams}

CARBOUT

$\mathrm{CO} 2$

$\mathrm{CO} 2 \mathrm{IN}$

CO2 TO STORAGE

$\mathrm{CO} 2+\mathrm{STEAM}$

$\mathrm{CO} 2+\mathrm{WATER}$

CRUSHED TRONA

FGPLANT

FLUE

FLUID OUT

HOT STEAM

HOT TRONA

MAKE UP

NA2CO3 COLD (Fig.5)

NA2CO3 COLD (Fig.6)

NA2CO3 HOT (Fig.5)

NA2CO3 HOT (Fig.6)

$\mathrm{NA} 2 \mathrm{CO} 3 \mathrm{IN}$

$\mathrm{NAHCO} 3$
Final product from carbonator

$\mathrm{CO}_{2}$ recovered from the system

$\mathrm{CO}_{2}$ entering the system

$\mathrm{CO}_{2}$ to the storage system $\left(20^{\circ} \mathrm{C}, 75 \mathrm{bar}\right)$

$\mathrm{CO}_{2}$ and steam $\left(220^{\circ} \mathrm{C}\right)$

$\mathrm{CO}_{2}$ and water $\left(95^{\circ} \mathrm{C}\right)$

Crushed Trona

Flue gas exits the coal fired plant

Flue gas exits the carbonator

Chemical products exits the fluidized bed reactor

Super heated steam $\left(205^{\circ} \mathrm{C}\right)$

Hot Trona $\left(125^{\circ} \mathrm{C}\right)$ entering the fluidized bed reactor

Sorbent Make up

Regenerated $\mathrm{Na}_{2} \mathrm{CO}_{3}\left(80^{\circ} \mathrm{C}\right)$

Cooled $\mathrm{Na}_{2} \mathrm{CO}_{3}\left(40{ }^{\circ} \mathrm{C}\right)$

Regenerated $\mathrm{Na}_{2} \mathrm{CO}_{3}\left(200^{\circ} \mathrm{C}\right)$

Hot $\mathrm{Na}_{2} \mathrm{CO}_{3}\left(220^{\circ} \mathrm{C}\right)$

Chemical products enteing the $\mathrm{NaHCO}_{3}$ production reactor

$\mathrm{NaHCO}_{3}$ produced by the system 


$\begin{array}{ll}\text { NAHCO3 COLD } & \text { Solids exits the carbonator }\left(60^{\circ} \mathrm{C}\right) \\ \text { NAHCO3 HOT } & \text { Solits entering the regenerator }\left(140^{\circ} \mathrm{C}\right) \\ \text { WATER IN (Fig.5) } & \text { Water } \mathrm{CO}_{2} \text { capture reactor } \\ \text { WATER IN (Fig.6) } & \text { Cold water }\left(35^{\circ} \mathrm{C}\right) \\ \text { WATER OUT } & \text { Process water }\end{array}$

\section{References}

6

11] Abanades JC, Rubin ES, Anthony EJ. Sorbent Cost and Performance in CO2 Capture Systems. Ind Eng Chem Res 2004:3462-6. doi:10.1021/ie049962v.

[2] Aresta M, Dibenedetto A, Angelini A. The changing paradigm in CO2 utilization. J CO2 Util 2013;3-4:65-73. doi:10.1016/j.jcou.2013.08.001.

[3] IEA. Carbon Capture and Storage Technologies 2016. http://www.iea.org/topics/ccs/ (accessed December 1, 2016).

[4] Zhang X, Singh B, He X, Gundersen T, Deng L, Zhang S. Post-combustion carbon capture technologies: Energetic analysis and life cycle assessment. Int J Greenh Gas Control 2014;27:289-98. doi:10.1016/j.ijggc.2014.06.016.

[5] Zhang W, Liu H, Sun Y, Cakstins J, Sun C, Snape CE. Parametric study on the regeneration heat requirement of an amine-based solid adsorbent process for post-combustion carbon capture. Appl Energy 2016;168:394-405. doi:10.1016/j.apenergy.2016.01.049.

[6] Lai S, Mani F, Passaponti M, Stoppioni P. Studio dei processi chimico-fisici di upgrading del biogas a biometano con separazione di CO 2 mediante assorbimento con soluzioni amminiche in solvente organico 2013.

[7] BAILEY RT, MCDONALD MM. CO2 CAPTURE AND USE FOR EOR IN WESTERN CANADA .1. GENERAL OVERVIEW. ENERGY Convers Manag 1993;34:1145-50. doi:10.1016/0196-8904(93)90063-G.

[8] Fujiki J, Chowdhury FA, Yamada H, Yogo K. Highly efficient post-combustion CO2 capture by low-temperature steam-aided vacuum swing adsorption using a novel polyamine-based solid sorbent. Chem Eng J 2017;307:273-82. doi:10.1016/j.cej.2016.08.071.

[9] Novek EJ, Shaulsky E, Fishman ZS, Pfefferle LD, Elimelech M. Low-Temperature Carbon Capture Using Aqueous Ammonia and Organic Solvents. Environ Sci Technol Lett 2016;3:291-6. doi:10.1021/acs.estlett.6b00253.

[10] Ma'mun S, Svendsen HF, Hoff KA, Juliussen O. Selection of new absorbents for carbon dioxide capture. Energy Convers Manag 2007;48:251-8. doi:10.1016/j.enconman.2006.04.007.

[11] Tan Y, Nookuea W, Li H, Thorin E, Yan J. Property impacts on Carbon Capture and Storage (CCS) processes: A review. Energy Convers Manag 2016;118:204-22. doi:10.1016/j.enconman.2016.03.079.

[12] Samanta A, Zhao A, Shimizu GKH, Sarkar P, Gupta R. Post-Combustion $\mathrm{CO}_{2}$ Capture Using Solid Sorbents: A Review. Ind Eng Chem Res 2012;51:1438-63. doi:10.1021/ie200686q.

[13] Joos L, Lejaeghere K, Huck JM, Van Speybroeck V, Smit B. Carbon capture turned upside down: high-temperature adsorption \&amp; low-temperature desorption (HALD). Energy Environ Sci 2015;8:2480-91. doi:10.1039/C5EE01690H.

[14] Fennell PS, Davidson JF, Dennis JS, Hayhurst AN. Regeneration of sintered limestone sorbents for the sequestration of $\mathrm{CO} 2$ from combustion and other systems. J Energy Inst 2007;80:116-9. doi:10.1179/174602207X189175. 
[15] Hammond GP, Spargo J. The prospects for coal-fired power plants with carbon capture and storage: A UK perspective. Energy Convers Manag 2014;86:476-89. doi:10.1016/j.enconman.2014.05.030.

[16] Hammond GP, Akwe SSO, Williams S. Techno-economic appraisal of fossil-fuelled power generation systems with carbon dioxide capture and storage. Energy 2011;36:975-84. doi:10.1016/j.energy.2010.12.012.

[17] Fu C, Gundersen T. Heat and work integration: Fundamental insights and applications to carbon dioxide capture processes. Energy Convers Manag 2016;121:36-48. doi:10.1016/j.enconman.2016.04.108.

[18] Stępczyńska-Drygas K, Łukowicz H, Dykas S. Calculation of an advanced ultra-supercritical power unit with CO2 capture installation. Energy Convers Manag 2013;74:201-8. doi:10.1016/j.enconman.2013.04.045.

[19] Qadir A, Sharma M, Parvareh F, Khalilpour R, Abbas A. Flexible dynamic operation of solar-integrated power plant with solvent based post-combustion carbon capture (PCC) process. Energy Convers Manag 2015;97:7-19. doi:10.1016/j.enconman.2015.02.074.

[20] Zhai R, Li C, Qi J, Yang Y. Thermodynamic analysis of CO2 capture by calcium looping process driven by coal and concentrated solar power. Energy Convers Manag 2016;117:25163. doi:10.1016/j.enconman.2016.03.022.

[21] Rahman FA, Aziz MMA, Saidur R, Bakar WAWA, Hainin M., Putrajaya R, et al. Pollution to solution: Capture and sequestration of carbon dioxide (CO2) and its utilization as a renewable energy source for a sustainable future. Renew Sustain Energy Rev 2017;71:11226. doi:10.1016/j.rser.2017.01.011.

[22] Joos L, Huck JM, Van Speybroeck V, Smit B. Cutting the cost of carbon capture: a case for carbon capture and utilization. Faraday Discuss 2016;192:391-414. doi:10.1039/C6FD00031B.

[23] Meisen A, Shuai X. Research and development issues in $\mathrm{CO} 2$ capture. Energy Convers Manag 1997;38:S37-42. doi:10.1016/S0196-8904(96)00242-7.

[24] Swaddle TW (Thomas W. Inorganic chemistry: an industrial and environmental perspective. Academic Press; 1997.

[25] Nelson TO, Coleman LJI, Green DA, Gupta RP. The dry carbonate process: Carbon dioxide recovery from power plant flue gas. Energy Procedia, vol. 1, Elsevier; 2009, p. 1305-11. doi:10.1016/j.egypro.2009.01.171.

[26] Nelson TO, Coleman LJI, Green DA, Gupta RP. The dry carbonate process: Carbon dioxide recovery from power plant flue gas. Energy Procedia 2009;1:1305-11. doi:10.1016/j.egypro.2009.01.171.

[27] Intratec Solutions. Chlorine Production from Sodium Chloride - Cost Analysis - Chlorine E11A - Intratec Solutions - Google Libros. 2016.

[28] Wyoming Mining Association. Wyoming Mining Association: Trona Mining n.d. http://www.wyomingmining.org/minerals/trona/ (accessed December 1, 2016).

[29] Harris RE. Fifty Years of Wyoming Trona Mining 1997:177-82.

[30] Manega PC, Bieda S. Modern sediments of Lake Natron, Tanzania. Sci Geol - Bull 1987;40:83-95.

[31] Eckardt FD, Drake N, Goudie AS, White K, Viles H. The role of playas in pedogenic gypsum crust formation in the Central Namib Desert: A theoretical model. Earth Surf Process Landforms 2001;26:1177-93. doi:10.1002/esp.264.

[32] Helvaci C. The Beypazari trona deposit, Ankara Province, Turkey. Proc First Int Soda Ash 1998.

[33] Zhang Y. Geology of the Wucheng trona deposit in Henan, China - Google Académico. Sixth Int. Symp. salt, 1985, p. 67-73.

[34] Vanderzee E. 1982, 14, 219-238. J Chem Thermodyn 1982;14:219-38. doi:10.1016/00219614(82)90013-1. 
[35] Berg RL, Vanderzee CE. Enthalpies of dilution of sodium carbonate and sodium hydrogen carbonate solutions, and the standard enthalpies of ionization of aqueous carbonic acid, at 298.15 K. J Chem Thermodyn 1978;10:1049-75. doi:10.1016/0021-9614(78)90080-0.

[36] Haynes HW. Thermodynamic solution model for trona brines. AIChE J 2003;49:1883-94. doi:10.1002/aic.690490724.

[37] Gärtner RS, Witkamp GJ. Wet calcining of trona (sodium sesquicarbonate) and bicarbonate in a mixed solvent. J Cryst Growth 2002;237:2199-204. doi:10.1016/S0022-0248(01)022758.

[38] Heda PK, Dollimore D, Alexander KS, Chen D, Law E, Bicknell P. A method of assessing solid state reactivity illustrated by thermal decomposition experiments on sodium bicarbonate. Thermochim Acta 1995;255:255-72. doi:10.1016/0040-6031(94)02154-G.

[39] Otsubo, Y., \& Yamaguchi K. THERMOCHEMICAL PROPERTIES AND REACTION PROCESSES OF ALKALI CARBONATE-FERRIC OXIDE SYSTEMS AS INVESTIGATED BY MEANS OF DIFFERENTIAL THERMAL METHOD. Nippon Kagaku Zasshi, 1961;82:557-60.

[40] Jared Sanford Sproul ER. US 3869538 A Process for producing sodium carbonate from trona. US3869538 A, 1973.

[41] R. S. GÄRTNER. MIXED SOLVENT REACTIVE RECRYSTALLIZATION OF SODIUM CARBONATE. Universität Dortmund, 2005.

[42] Ciferno JP, Fout TE, Jones AP, Murphy JT. Capturing Carbon from Existing Coal-Fired Power Plants. Chem Eng Prog 2009;105:33-41.

[43] Romeo LM, Abanades JC, Escosa JM, Paño J, Giménez A, Sánchez-Biezma A, et al. Oxyfuel carbonation/calcination cycle for low cost $\mathrm{CO} 2$ capture in existing power plants. Energy Convers Manag 2008;49:2809-14. doi:10.1016/j.enconman.2008.03.022.

[44] D. Bonaventura, R. Chacartegui, J.M Valverde JAB. Dry Carbonate process for CO2 capture, SDEWES.SEE2016.0073. 2nd SDEWES SEE, Piran: SDEWES Centre; 2016.

[45] J. Carlos Abanades *,†, G. Grasa †, M. Alonso †, N. Rodriguez †, E. J. Anthony $\S$ and, Romeoll LM. Cost Structure of a Postcombustion CO2 Capture System Using CaO 2007. doi:10.1021/ES070099A.

[46] FMC Soda Ash Plant, Wyoming - Chemicals Technology n.d. http://www.chemicalstechnology.com/projects/sodaash/ (accessed December 1, 2016).

[47] Solare Termodinamico Fonte Enea 2016. http://energia.regione.emiliaromagna.it/documenti/doc-fonti-rinnovabili/solare-termodinamico-fonte-enea (accessed December 1, 2016).

[48] Guo Z, Wang Q, Fang M, Luo Z, Cen K. Thermodynamic and economic analysis of polygeneration system integrating atmospheric pressure coal pyrolysis technology with circulating fluidized bed power plant. Appl Energy 2014;113:1301-14. doi:10.1016/j.apenergy.2013.08.086.

[49] Market Pubblisher. Global Sodium Bicarbonate Industry Market Research 2016. 2016. 


\section{Figures Captions}

$4 \quad$ Figure 1. Flow diagram of the research triangle institute (RTI) dry carbonate process for $\mathrm{CO}_{2}$ capture coupled to $\mathrm{NaHCO}_{3}$ production using raw trona and assisted by medium temperature solar thermal power.

Figure 2. Sankey diagram of $\mathrm{CO}_{2}$ patterns in the overall process

Figure 3. Integration of the RTI dry carbonate process into a CFPP for $\mathrm{CO}_{2}$ capture [44].

Figure 4. $\mathrm{Na}_{2} \mathrm{CO}_{3}$ and $\mathrm{NaHCO}_{3}$ production from trona assisted by solar energy.

Figure 5. SPB as a function of solar thermal technology costs for the different scenarios analyzed.

Figure 6. Best Estimate Scenario: NPV in 20 years as function of internal rate value and solar thermal technology costs.

Figure 7. Optimistic Scenario: NPV in 20 years as function of internal rate value and solar thermal technology costs.

Figure 8. Pessimistic Scenario: NPV in 20 years as function of internal rate value and solar thermal technology costs.

Figure 9. NPV in 20 years as function of $\mathrm{NaHCO}_{3}$ production and solar technology costs for a fixed discount rate $\mathrm{IR}=0.1$.

Figure 10. Best Estimated Scenario: Economic Gain due to $\mathrm{CO}_{2}$ avoided emissions.

Figure 11. Optimistic Scenario: Economic Gain due to $\mathrm{CO}_{2}$ avoided emissions.

Figure 12. Pessimistic Scenario: Economic Gain due to $\mathrm{CO}_{2}$ avoided emissions.

Figure 13. NPV in 20 years as function of investment costs and $\mathrm{NaHCO}_{3}$ price with $100 \%$ of $\mathrm{NaHCO}_{3}$ total production.

Figure 14. NPV in 20 years as function of investment costs and $\mathrm{NaHCO}_{3}$ price with $75 \%$ of $\mathrm{NaHCO}_{3}$ total production.

Figure 15. NPV in 20 years as function of investment costs and $\mathrm{NaHCO}_{3}$ price with $50 \%$ of $\mathrm{NaHCO}_{3}$ total production. 


\section{Tables Captions}

2 Table 1. Natural trona composition [20].

4 Table 2. Best fitting parameters used in the model for the equilibrium constant $\mathrm{K}_{\mathrm{s}}$ (Eq. 15) of the reactions involved in $\mathrm{NaHCO}_{3}$ production from raw trona.

Table 3: Power consumption for the reference CFPP $[42,43]$

Table 4: Flue gas flow composition from the reference CFPP $[42,43]$.

Table 5. Power consumption for a $15 \mathrm{MWel}$ CFPP with integrated RTI dry carbonate process for $\mathrm{CO}_{2}$ capture.

14 Table 6. Heat exchanged in $\mathrm{NaHCO}_{3}$ production according to Fig. 3.

16 Table 7. Flow rates of streams entering and exiting the fluidized bed reactor in the $\mathrm{NaHCO}_{3}$ production according to Fig. 3 .

Table 8. Heat requirement in different components for the production of $\mathrm{NaHCO}_{3}$.

Table 9. Compression power for $\mathrm{NaHCO}_{3}$ production.

Table 10. Different prices for different scenarios.

Table 11: Total investment cost: $\mathrm{NaHCO}_{3}$ production + Solar Thermal.

Table 12: Total Investment costs and yearly revenue for scenarios of analysis.

Table 13: $\mathrm{CO}_{2}$ emission data for different scenarios.

Table 14: Revenues due to $\mathrm{CO}_{2}$ emission reduction for different scenarios (20 years).

Table 15:NPV(20 years) values including savings from $\mathrm{CO}_{2}$ emission reduction. 


\section{Figures}

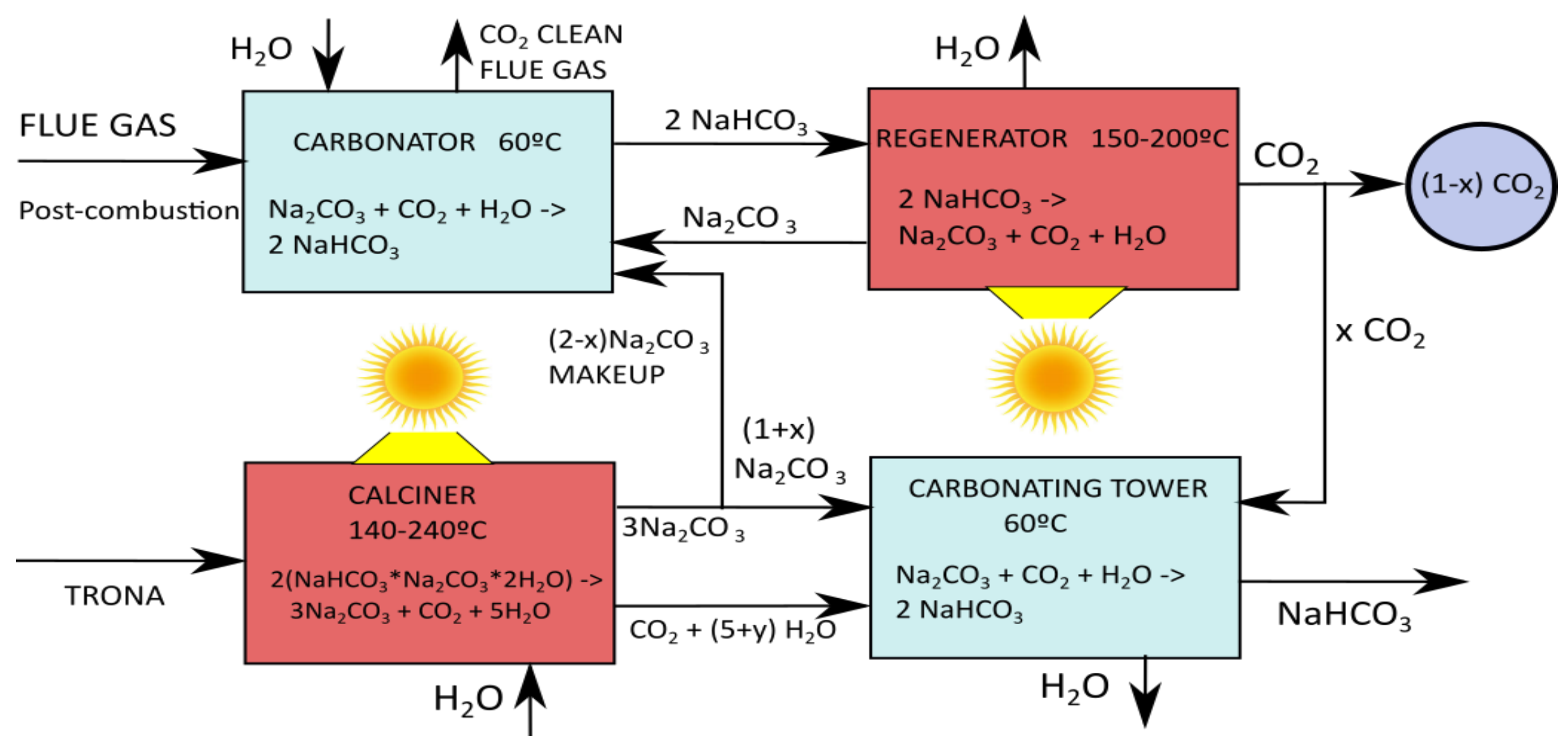
trona and assisted by medium temperature solar thermal power. 


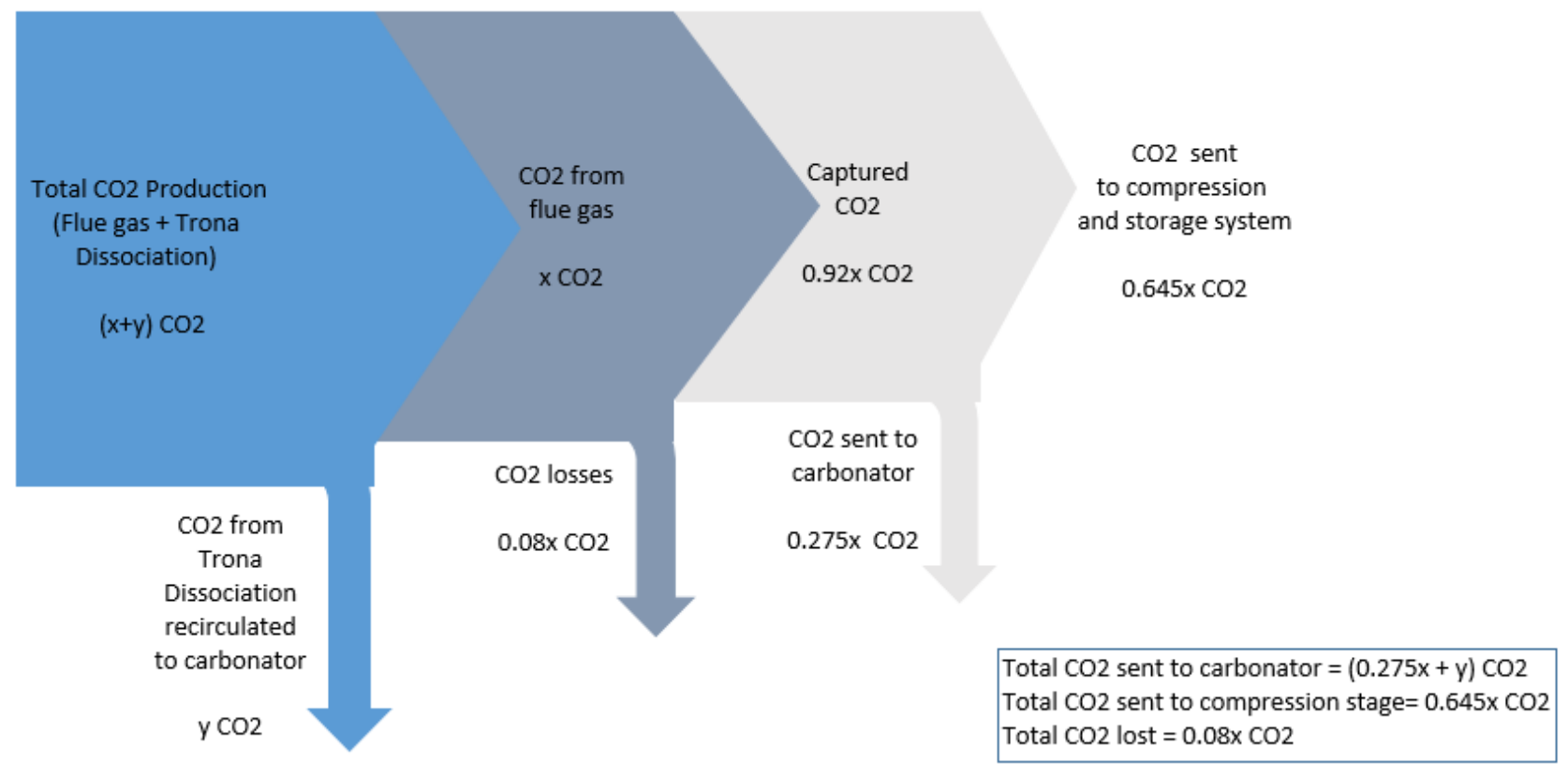

Figure 2. Sankey diagram of $\mathrm{CO}_{2}$ routes in the overall process 


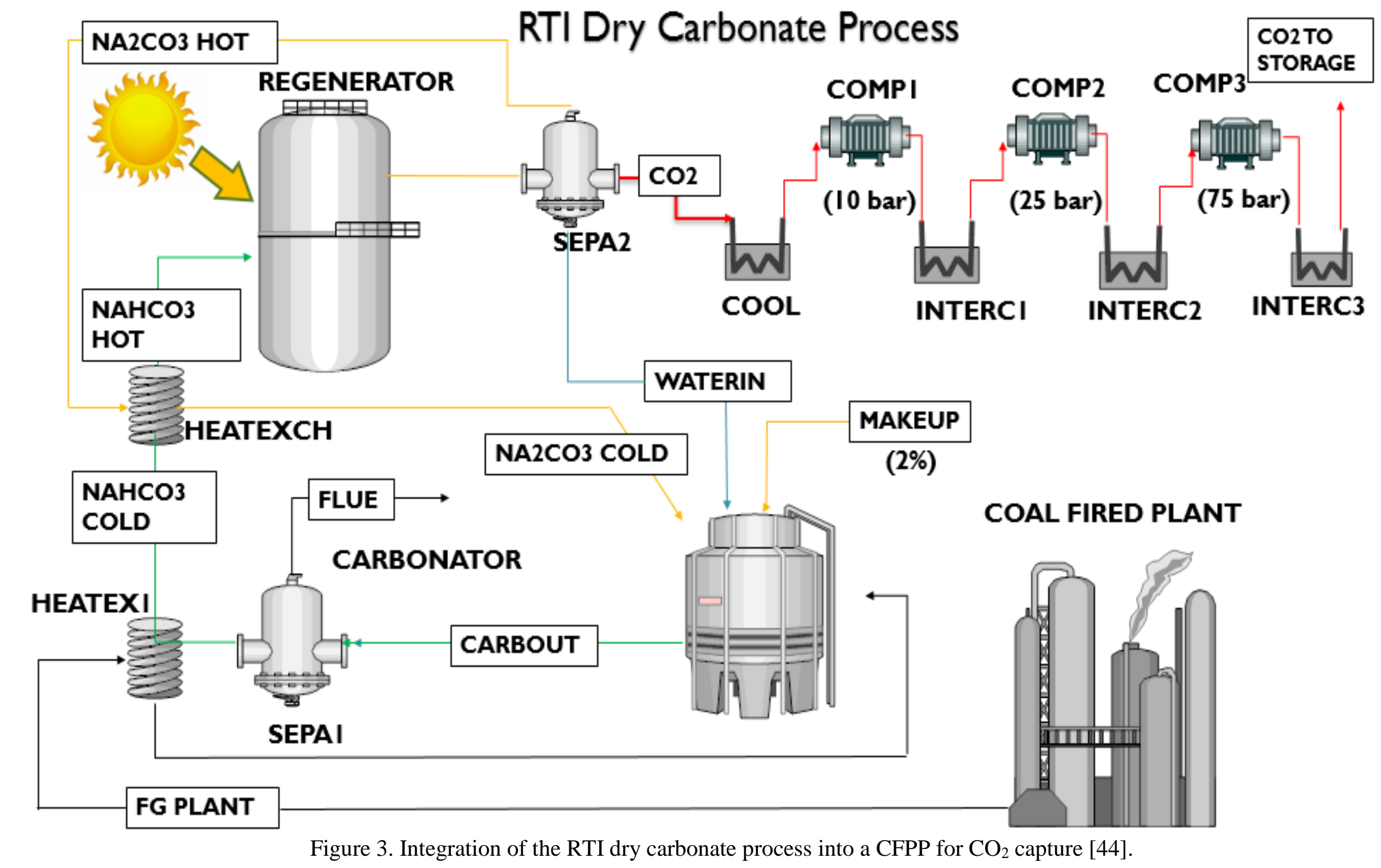




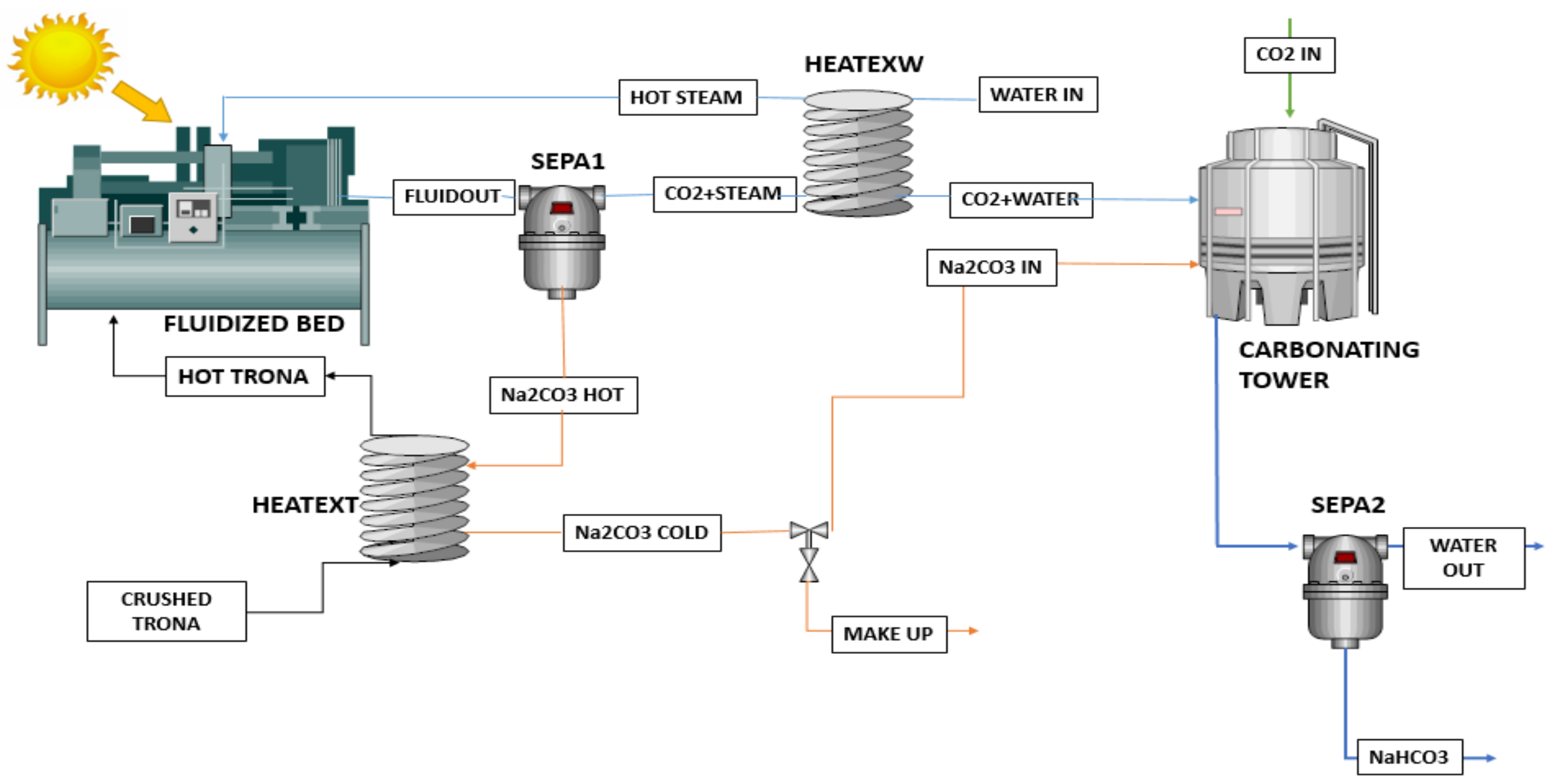

Figure $4 . \mathrm{Na}_{2} \mathrm{CO}_{3}$ and $\mathrm{NaHCO}_{3}$ production from trona assisted by solar energy. 


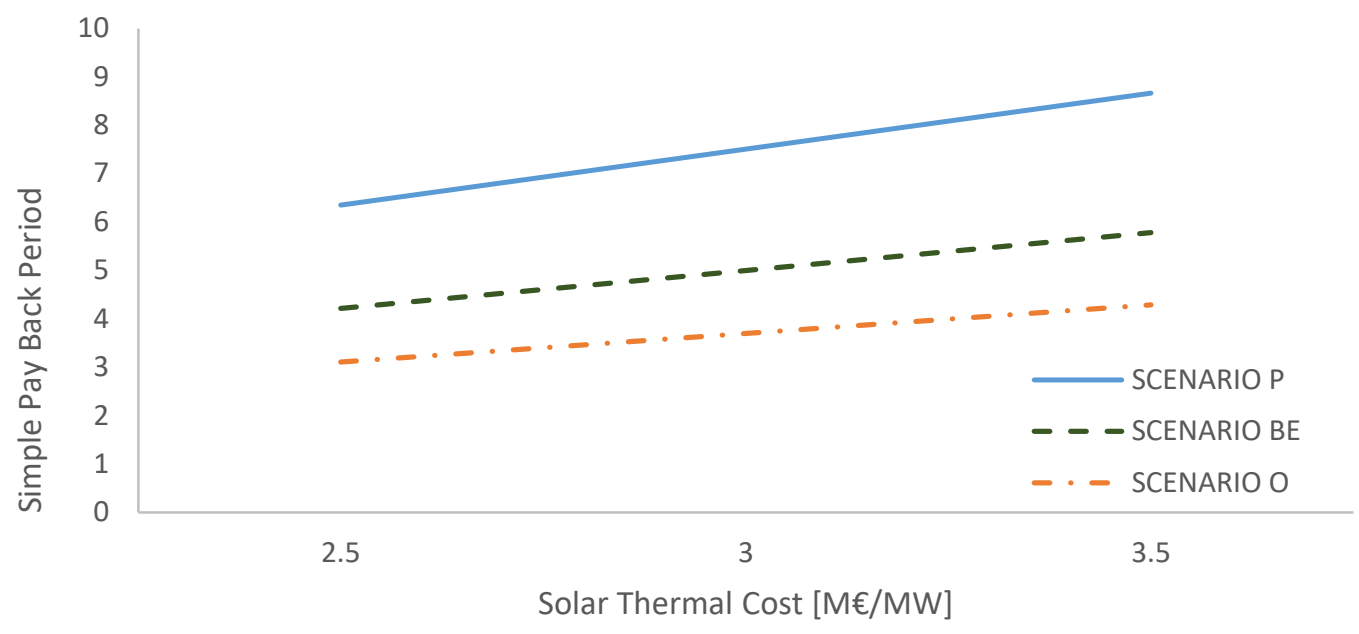

4 Figure 5. SPB as a function of solar thermal technology costs for the different scenarios analyzed. 


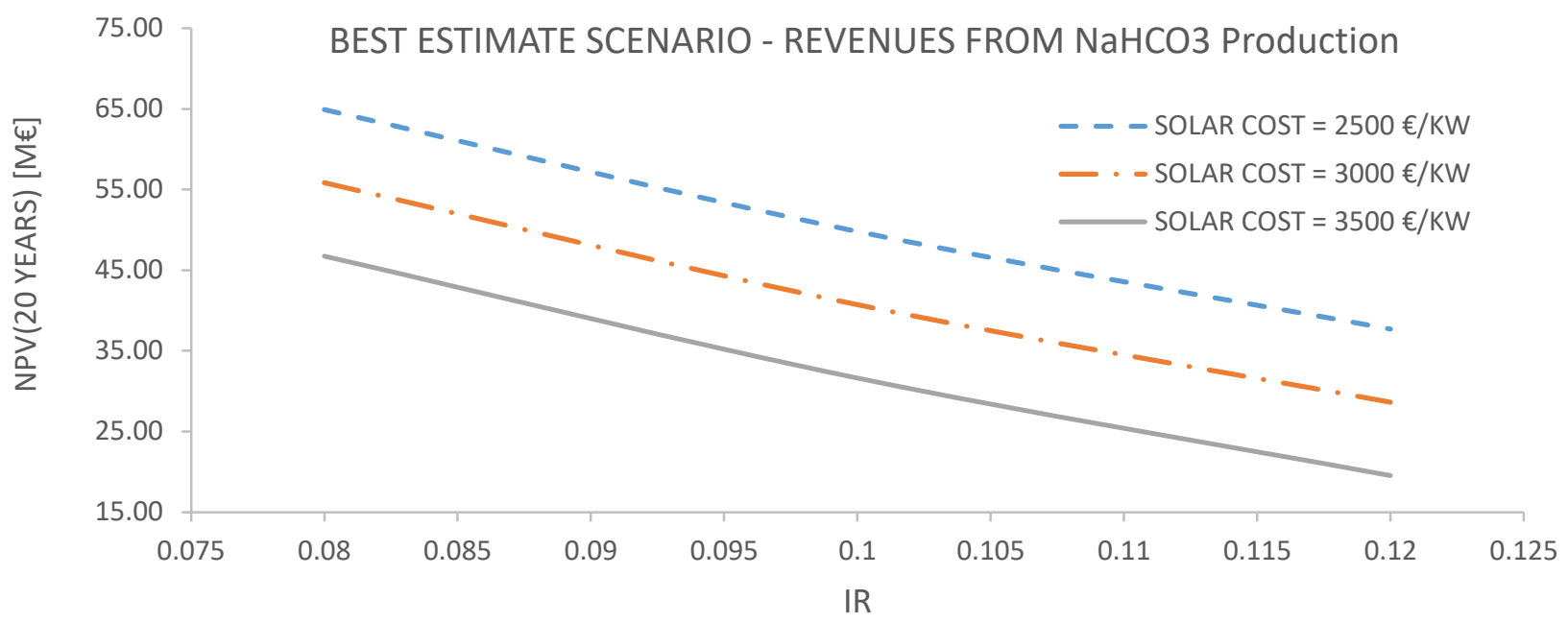

2

Figure 6. Best Estimate Scenario: NPV in 20 years as function of internal rate value and solar thermal technology costs.

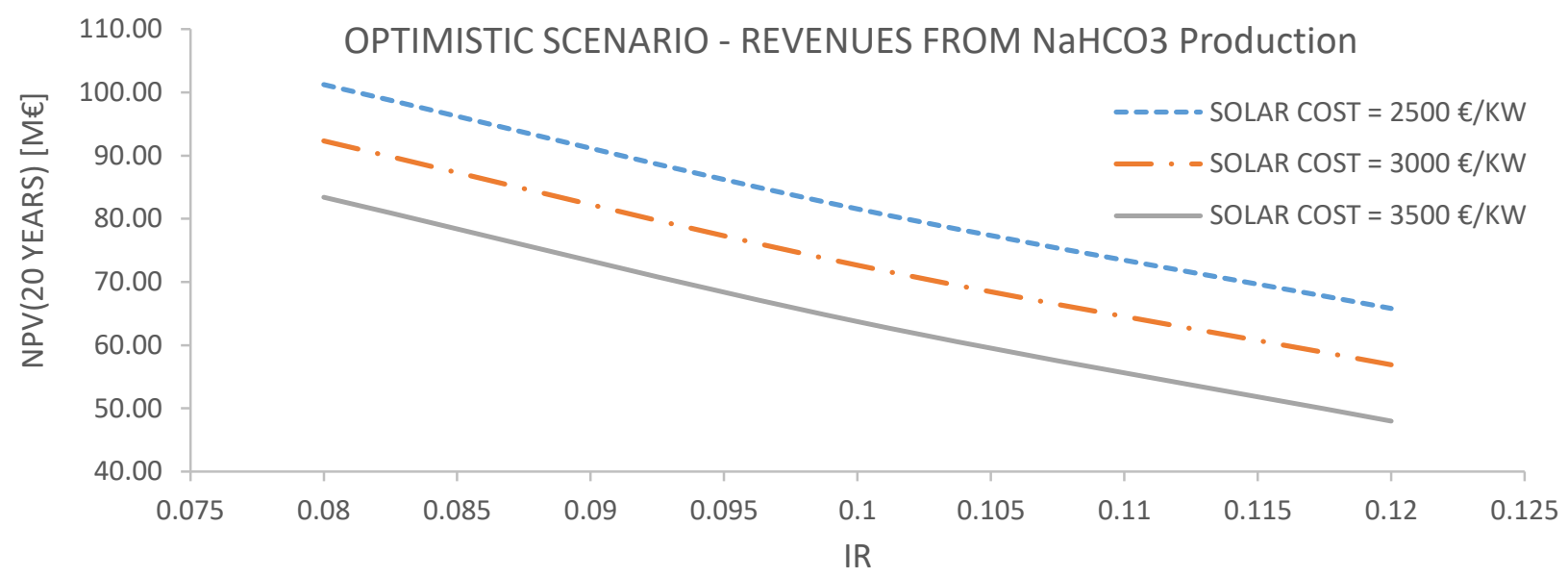

Figure 7. Optimistic Scenario: NPV in 20 years as function of internal rate value and solar thermal technology costs.

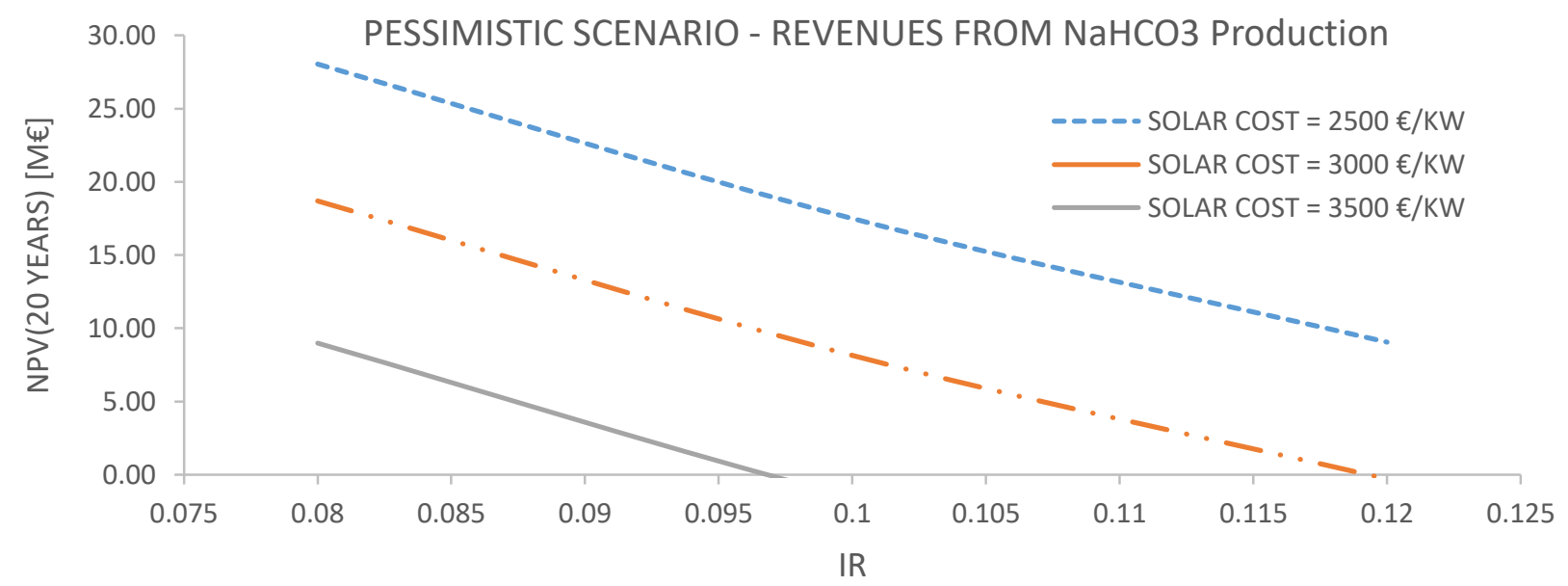

Figure 8. Pessimistic Scenario: NPV in 20 years as function of internal rate value and solar thermal technology costs. 


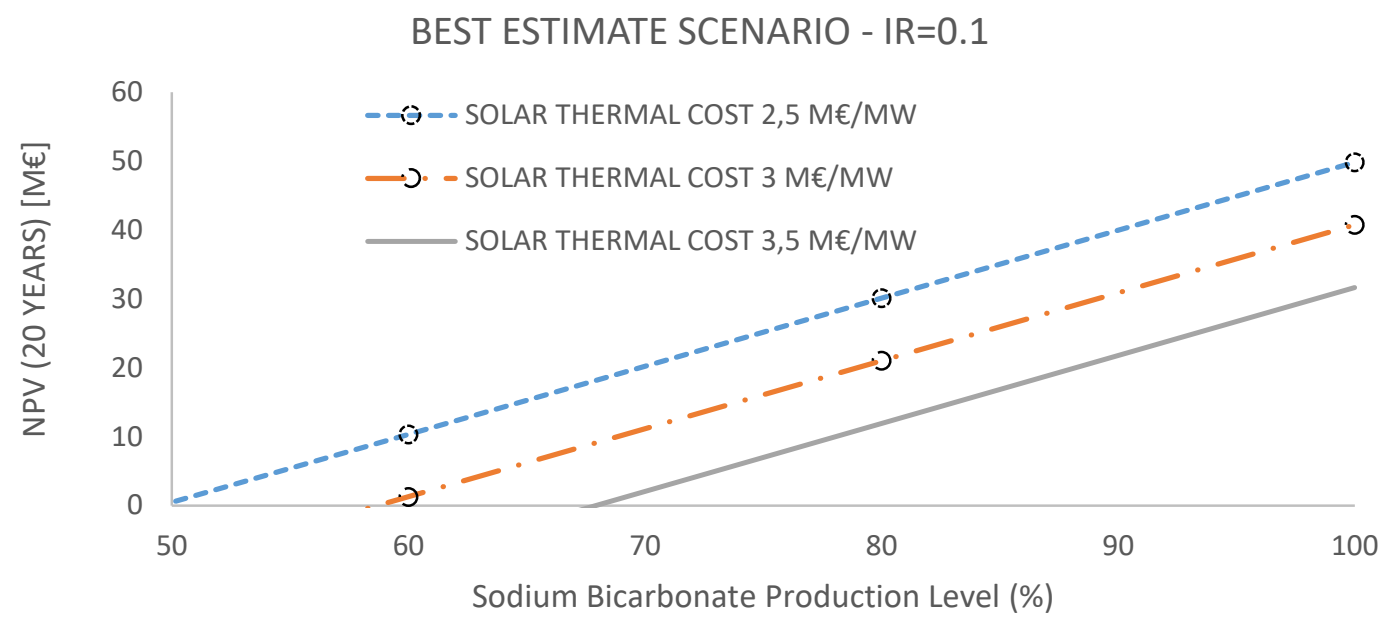

10

Figure 9. NPV in 20 years as function of $\mathrm{NaHCO}_{3}$ production and solar technology costs for a fixed 12 discount rate $\mathrm{IR}=0.1$. 


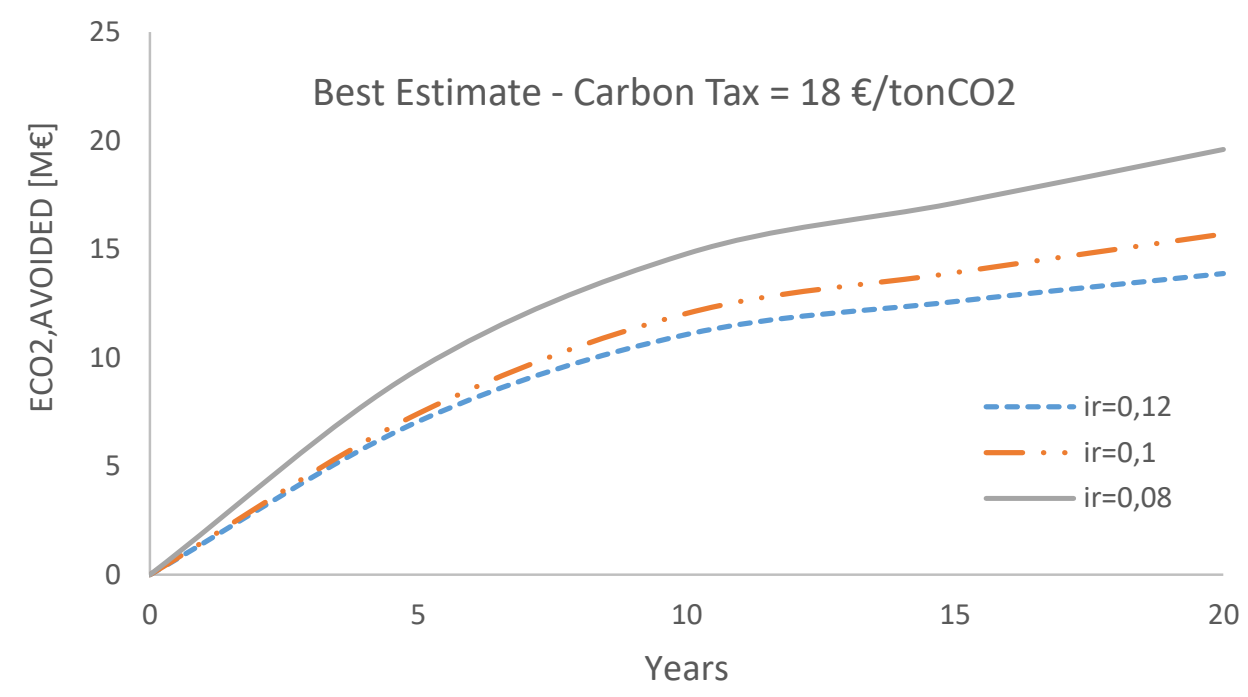

Figure 10. Best Estimated Scenario: Economic Gain due to $\mathrm{CO}_{2}$ avoided emissions.

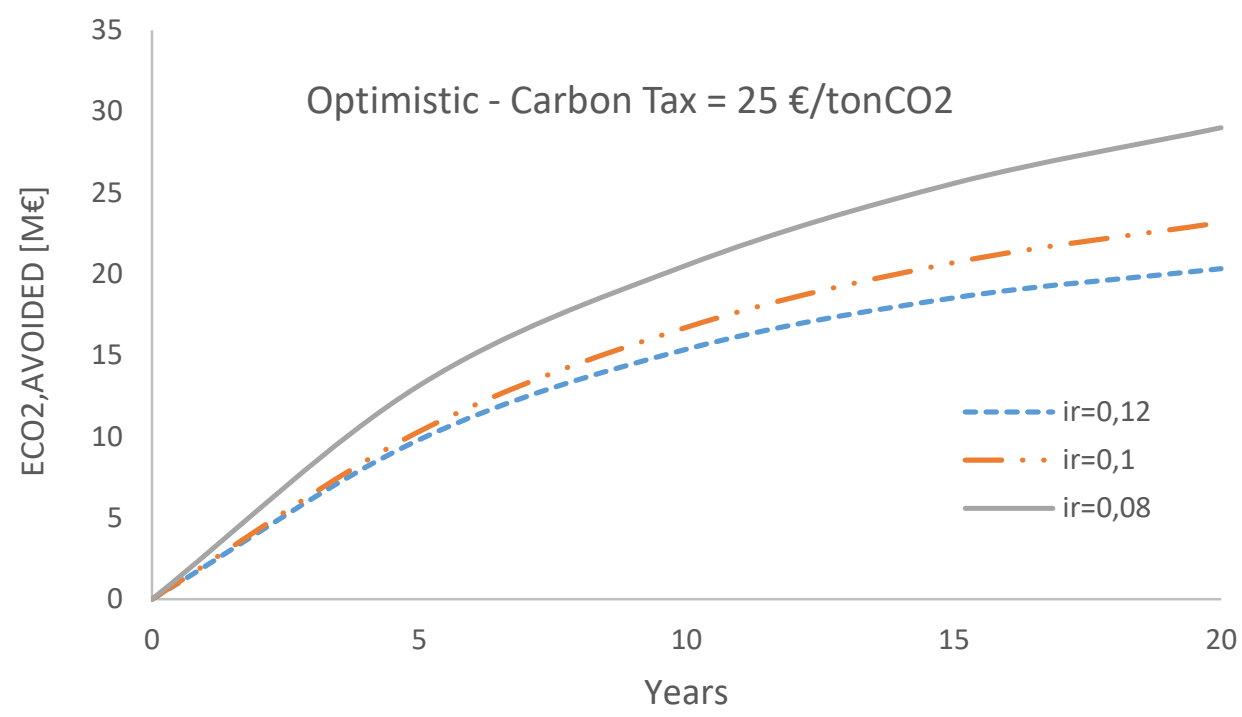

Figure 11. Optimistic Scenario: Economic Gain due to $\mathrm{CO}_{2}$ avoided emissions.

6

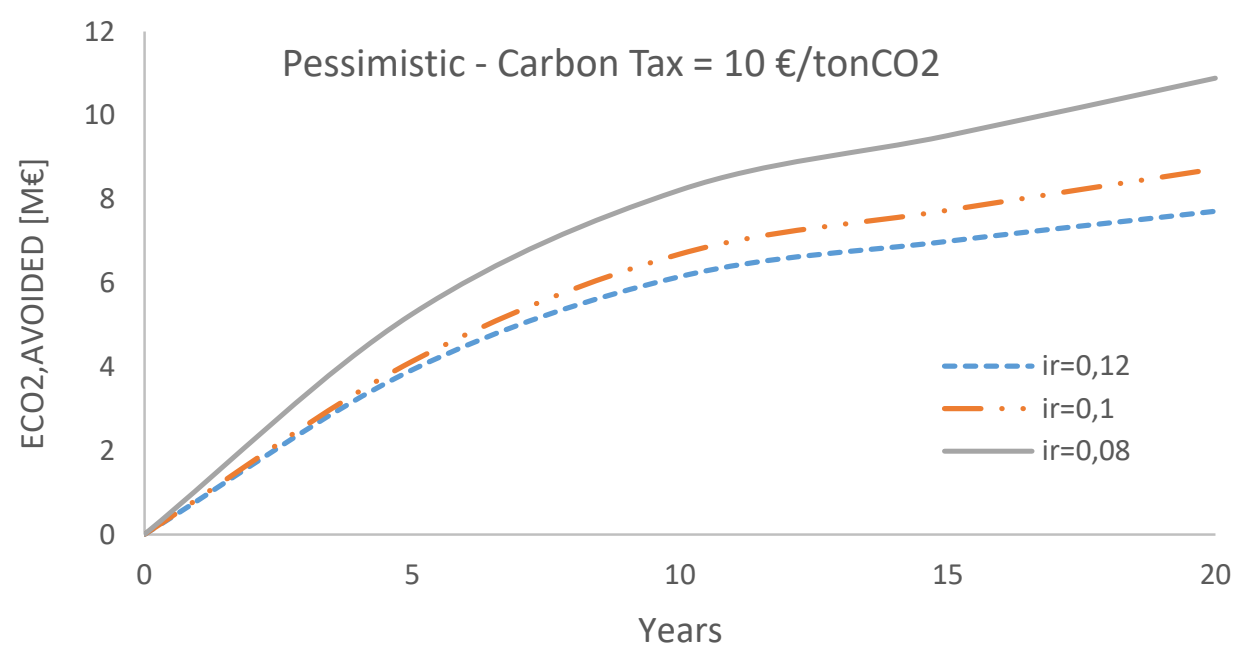

Figure 12. Pessimistic Scenario: Economic Gain due to $\mathrm{CO}_{2}$ avoided emissions. 


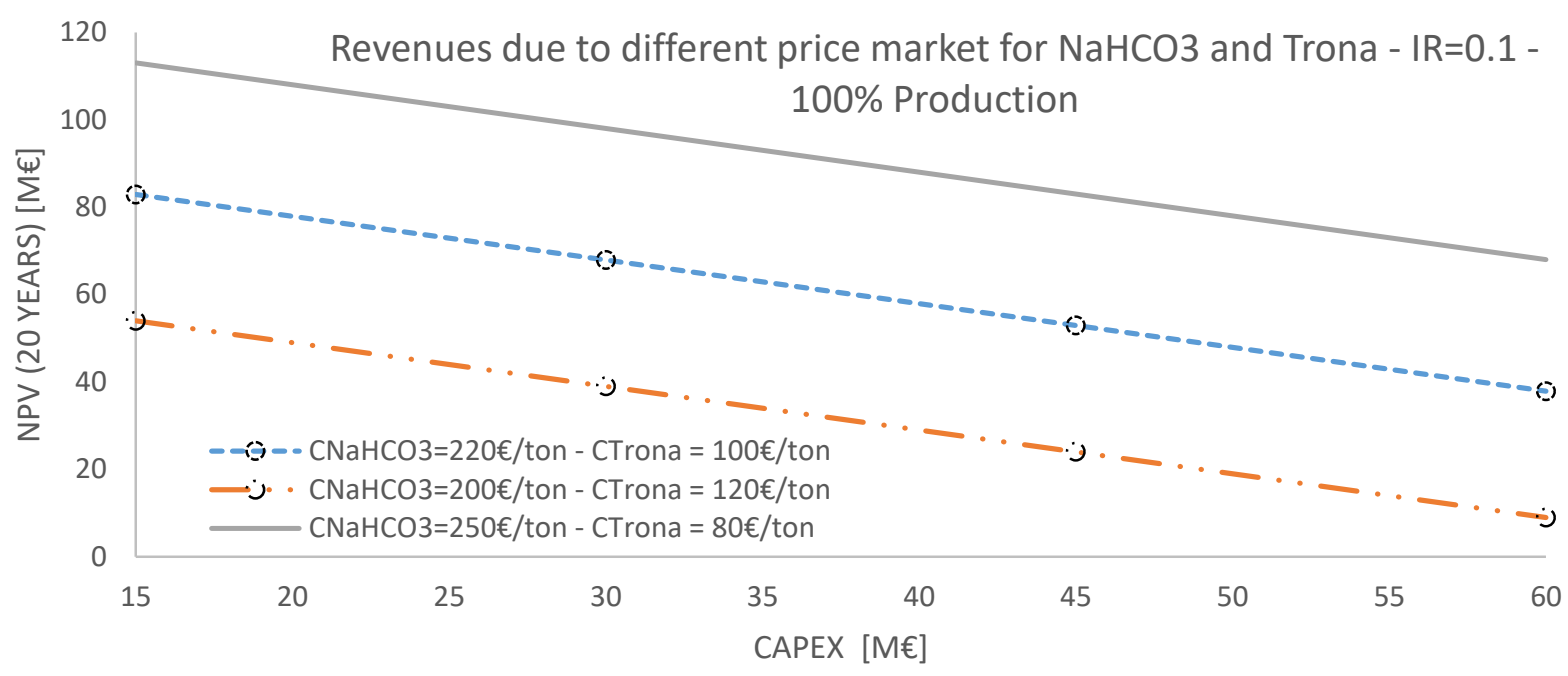

Figure 13. NPV in 20 years as function of investment costs and $\mathrm{NaHCO}_{3}$ price with $100 \%$ of $\mathrm{NaHCO}_{3}$ total production.

4

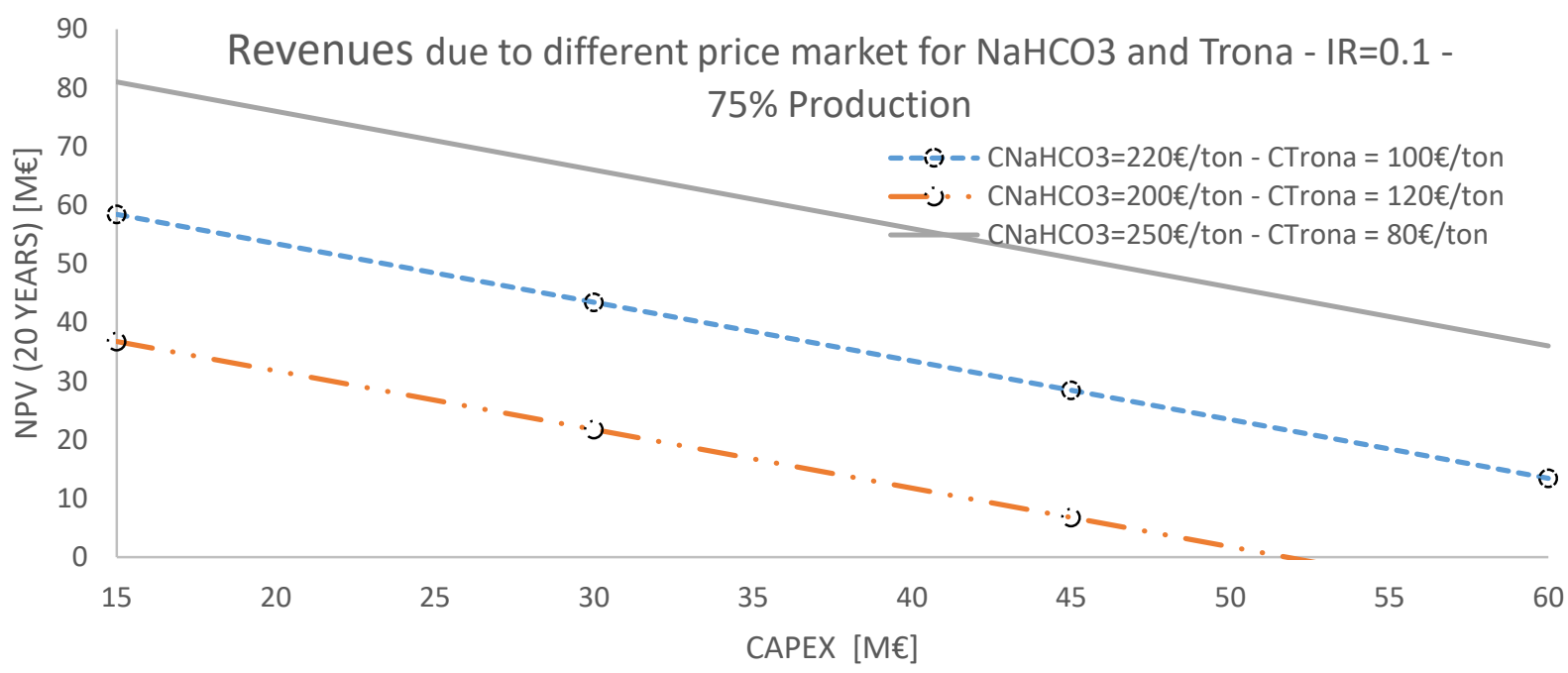

Figure 14. NPV in 20 years as function of investment costs and $\mathrm{NaHCO}_{3}$ price with $75 \%$ of $\mathrm{NaHCO}_{3}$ total production.

8

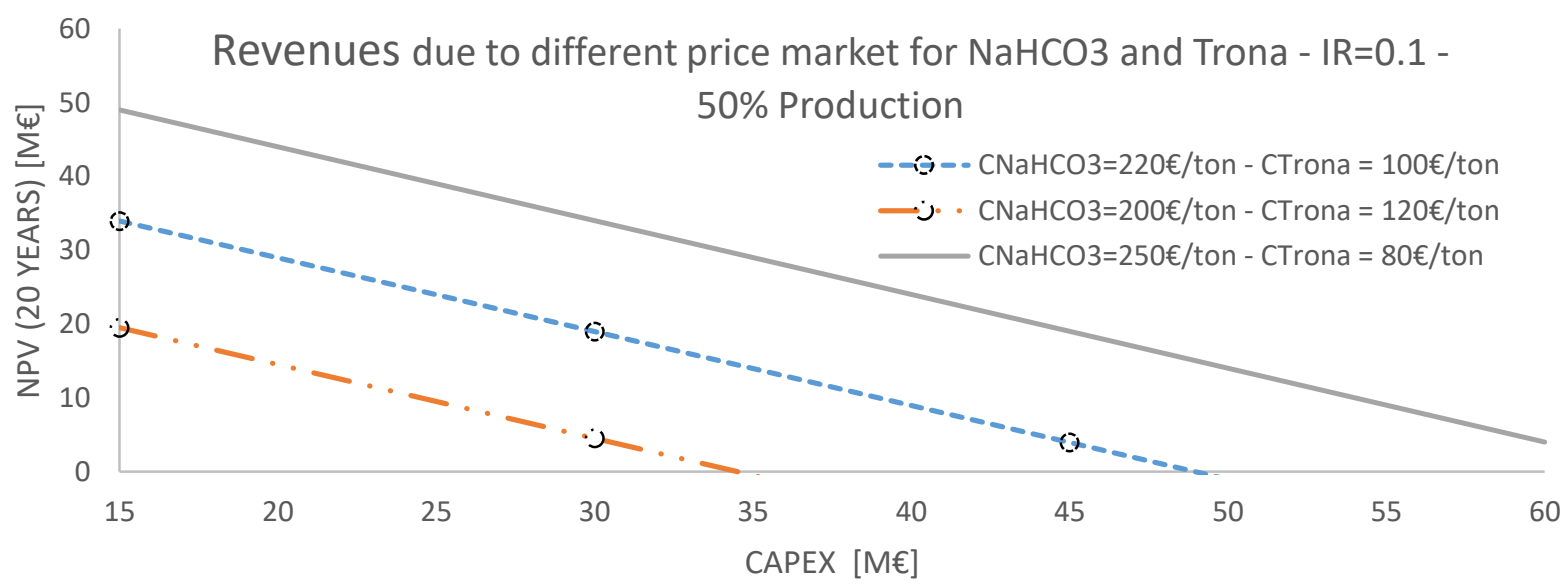

Figure 15. NPV in 20 years as function of investment costs and $\mathrm{NaHCO}_{3}$ price with $50 \%$ of $\mathrm{NaHCO}_{3}$ total production. 
Table 1. Natural trona composition [20].

\begin{tabular}{l|l}
\hline Component & $\mathrm{Wt} \%$ \\
\hline $\mathrm{Na}_{2} \mathrm{CO}_{3}$ & 46,53 \\
\hline $\mathrm{NaHCO}_{3}$ & 34,82 \\
\hline $\mathrm{Na}_{2} \mathrm{SO}_{4}$ & 0,568 \\
\hline insolubles & 2,98 \\
\hline hydration water & 14,92 \\
\hline others & 0,182 \\
\hline
\end{tabular}

Table 2. Best fitting parameters used in the model for the equilibrium constant $\mathrm{K}_{\mathrm{s}}$ (Eq. 15) of the reactions involved in $\mathrm{NaHCO}_{3}$ production from raw trona.

\begin{tabular}{c|c|c|c|c}
\hline & $\mathrm{A}$ & $\mathrm{B}$ & $\mathrm{C}$ & $\mathrm{D}$ \\
\hline $\mathrm{REACTIONS}$ & & & & \\
\hline $\mathrm{CO}_{2}+2 \mathrm{H}_{2} \mathrm{O} \leftrightarrows \mathrm{H}_{3} \mathrm{O}^{+}+\mathrm{HCO}_{3}^{-}$ & 231.47 & -12092.7 & -36.78 & 0 \\
\hline $\mathrm{HCO}_{3}^{-}+\mathrm{H}_{2} \mathrm{O} \leftrightarrows \mathrm{H}_{3} \mathrm{O}^{+}+\mathrm{CO}_{3}^{-}$ & 216.05 & -1243.7 & -35.48 & 0 \\
\hline $\mathrm{NaHCO}_{3} \leftrightarrows \mathrm{Na}^{+}+\mathrm{HCO}_{3}^{-}$ & -63.26 & -1308.41 & 13.48 & -0.034 \\
\hline $\mathrm{Na}_{2} \mathrm{CO}_{3} \leftrightarrows 2 \mathrm{Na}^{+}+\mathrm{CO}_{3}^{-}$ & -548.32 & 18070.74 & 94.75 & -0.165 \\
\hline $\mathrm{Na}_{2} \mathrm{CO}_{3} \cdot \mathrm{H}_{2} \mathrm{O} \leftrightarrows 2 \mathrm{Na}^{+}+\mathrm{CO}_{3}^{-}+\mathrm{H}_{2} \mathrm{O}$ & 281.77 & -9970.6 & -44.56 & 0.0221 \\
\hline $\mathrm{Na}_{2} \mathrm{CO}_{3} \cdot 7 \mathrm{H}_{2} \mathrm{O} \leftrightarrows 2 \mathrm{Na}^{+}+\mathrm{CO}_{3}^{-}+7 \mathrm{H}_{2} \mathrm{O}$ & 484.91 & -18935 & -80.12 & 0.114 \\
\hline $\mathrm{Na}_{2} \mathrm{CO}_{3} \cdot 10 \mathrm{H}_{2} \mathrm{O} \leftrightarrows 2 \mathrm{Na}^{+}+\mathrm{CO}_{3}^{-}+10 \mathrm{H}_{2} \mathrm{O}$ & 1165.01 & -37.81 & -200.08 & 0.335 \\
\hline $2\left(\mathrm{Na}_{2} \mathrm{CO}_{3} \cdot \mathrm{NaHCO}_{3} \cdot 2 \mathrm{H}_{2} \mathrm{O} \leftrightarrows 5 \mathrm{Na}^{+}+\mathrm{CO}_{3}^{--}\right.$ & & & & \\
$+\mathrm{HCO}$ & 277.24 & -14523.8 & -41.0 & 0.0085 \\
\hline $\mathrm{Na}_{2} \mathrm{CO}_{3} \cdot 3 \mathrm{NaHCO}_{3} \leftrightarrows 5 \mathrm{Na}^{+}+\mathrm{CO}_{3}^{--}+3 \mathrm{HCO}_{3}^{-}$ & -1209.46 & 29113.05 & 213.72 & -0.363 \\
\hline
\end{tabular}

8

10

Table 3: Power consumption for the reference CFPP [42,43]

\begin{tabular}{l|l|l}
\hline Item & Magnitude & Unit \\
\hline Coal consumption & 6.1 & $\mathrm{t} / \mathrm{h}$ \\
\hline Air in & 69.2 & $\mathrm{t} / \mathrm{h}$ \\
\hline Gross power introduced & 44.7 & $\mathrm{MW}_{\text {th }}$ \\
\hline Net power introduced & 39.7 & $\mathrm{MW}_{\text {th }}$ \\
\hline Net Power Produced & 15 & $\mathrm{MW}_{\mathrm{el}}$ \\
\hline Net efficiency & 33.5 & $\%$ \\
\hline
\end{tabular}


Table 4: Flue gas flow composition from the reference CFPP [42,43].

\begin{tabular}{c|c|c}
\hline Coal flue gas component & Mole Flow $(\mathrm{kmol} / \mathrm{h})$ & Mass Flow $(\mathrm{t} / \mathrm{h})$ \\
\hline $\mathrm{N}_{2}$ & 1715.42 & 52.97 \\
\hline $\mathrm{CO}_{2}$ & 308.56 & 13.60 \\
\hline $\mathrm{H}_{2} \mathrm{O}$ & 147.19 & 2.94 \\
\hline $\mathrm{O}_{2}$ & 78.18 & 2.76 \\
\hline $\mathrm{CO}$ & 14.07 & 0.39 \\
\hline $\mathrm{NO}$ & 13.54 & 0.45 \\
\hline $\mathrm{SO}_{2}$ & 3.75 & 0.26 \\
\hline
\end{tabular}

6

8 Table 5. Power consumption for a $15 \mathrm{MW}_{\mathrm{el}} \mathrm{CFPP}$ with integrated RTI dry carbonate process for $\mathrm{CO}_{2}$ capture.

\begin{tabular}{l|l|l}
\hline & Power production & Power consumption \\
\hline CFFP & $15 \mathrm{MW}_{\mathrm{el}}$ & $44.7 \mathrm{MW}_{\mathrm{th}}$ \\
\hline Regenerator & & $11.4 \mathrm{MW}_{\mathrm{th}}$ \\
\hline COMP & & $1.33 \mathrm{MW}_{\mathrm{el}}$ \\
\hline Wsolid & & $0.25 \mathrm{MW}_{\mathrm{el}}$ \\
\hline Centrifugation & & $0.3 \mathrm{MW}_{\mathrm{el}}$ \\
\hline Net Power & $13.12 \mathrm{MW}_{\mathrm{el}}$ & \\
\hline Total heat requirement & & $56.1 \mathrm{MW}_{\mathrm{th}}$ \\
\hline
\end{tabular}

10

12

14

Table 6. Heat exchanged in $\mathrm{NaHCO}_{3}$ production according to Fig. 3.

\begin{tabular}{l|r|r|r|r|r}
\hline & \multicolumn{1}{|c|}{$\mathrm{MW}_{\text {th }}$} & $\mathrm{T}_{\text {incold }}\left({ }^{\circ} \mathrm{C}\right)$ & $\mathrm{T}_{\text {outhot }}\left({ }^{\circ} \mathrm{C}\right)$ & $\mathrm{T}_{\text {inhot }}\left({ }^{\circ} \mathrm{C}\right)$ & $\mathrm{T}_{\text {outcold }}\left({ }^{\circ} \mathrm{C}\right)$ \\
\hline HEATEXCT & 1.15 & 20 & 95 & 219 & 205 \\
\hline HEATEXW & 0.7 & 20 & 40 & 219 & 127 \\
\hline Total Thermal Power & 1.85 & & & & \\
\hline
\end{tabular}


6 Table 7. Flow rates of streams entering and exiting the fluidized bed reactor in the $\mathrm{NaHCO}_{3}$ production according to Fig. 3.

\begin{tabular}{c|c|c|c|c}
\hline & Units & TRONA & WATIN & FLUIDOUT \\
\hline TRONA & $\mathrm{kmol} / \mathrm{h}$ & 84.709 & 0 & 0 \\
\hline WATER & $\mathrm{kmol} / \mathrm{h}$ & 0.387 & 85 & 307.5 \\
\hline $\mathrm{CO}_{2}$ & $\mathrm{kmol} / \mathrm{h}$ & 0.002 & 0 & 42.5 \\
\hline $\mathrm{WEGSC}(\mathrm{S})_{\mathrm{NaHCO}}$ & $\mathrm{kmol} / \mathrm{h}$ & 0.096 & 0 & 0 \\
\hline $\mathrm{Na}_{2} \mathrm{CO}_{3}$ & $\mathrm{kmol} / \mathrm{h}$ & 0.198 & 0 & 0 \\
\hline Mole Flow & $\mathrm{kmol} / \mathrm{h}$ & 0 & 0 & 127.5 \\
\hline Temperature & $\mathrm{kmol} / \mathrm{h}$ & 146.391 & 85 & 613.5 \\
\hline Pressure & ${ }^{\circ} \mathrm{C}$ & 127 & 204 & 219 \\
\hline Vapor Fraction & $\mathrm{bar}$ & 1.01 & 1.01 & 1,01 \\
\hline Solid Fraction & & 0 & 1 & 0.733 \\
\hline Mass Density & & 1 & 0 & 0.267 \\
\hline Average Molecular Weight & & 224 & 18.015 & 43.81 \\
\hline
\end{tabular}

Table 8. Heat requirement in different components for the production of $\mathrm{NaHCO}_{3}$.

\begin{tabular}{l|c|c}
\hline & $\mathrm{T}\left({ }^{\circ} \mathrm{C}\right)$ & Thermal Power consumption \\
\hline CFFP & 850 & $44.7 \mathrm{MW}_{\mathrm{th}}$ \\
\hline Regenerator & 200 & $11.4 \mathrm{MW}_{\mathrm{th}}$ \\
\hline Fluidized bed reactor & 220 & $5.1 \mathrm{MW}_{\mathrm{el}}$ \\
\hline Total heat requirement & & $61.2 \mathrm{MW}_{\mathrm{th}}$ \\
\hline
\end{tabular}

Table 9. Compression power for $\mathrm{NaHCO}_{3}$ production.

\begin{tabular}{l|r}
\hline Component & $\mathrm{W}_{\text {comp }}\left(\mathrm{MW}_{\mathrm{el}}\right)$ \\
\hline Compressor 1 ( 4.2 bar ) & 0.295 \\
\hline Compressor 2 (17.5 bar ) & 0.289 \\
\hline Compressor 3 ( 75 bar ) & 0.295 \\
\hline Total $\mathrm{W}_{\text {comp }}$ ( from 1 to 75 bar ) & 0.879 \\
\hline
\end{tabular}


Table 10. Different prices for different scenarios.

\begin{tabular}{c|c|c|c|c}
\hline & Units & Scen. P & Scen. BE & Scen. O \\
\hline$p_{\text {trona }}$ & $€ /$ ton & 120 & 100 & 80 \\
\hline $\mathrm{p}_{\text {NaHCO3 }}$ & $€ /$ ton & 200 & 220 & 240 \\
\hline$\Delta_{\text {Gain }}$ & $€ /$ ton & 80 & 120 & 160 \\
\hline $\mathrm{E}_{\text {GAIN }}$ & $€ /$ day & 22000 & 32000 & 44000 \\
\hline
\end{tabular}

6

Table 11: Total investment cost: $\mathrm{NaHCO}_{3}$ production + Solar Thermal.

\begin{tabular}{c|c|c|c|c}
\hline \multicolumn{5}{c}{ Solar Thermal $2.5 \mathrm{M} €$ /MW } \\
\hline & Units & Scen. P & Scen. BE & Scen. O \\
\hline EsOLAR (FLUID+DECARB) & M€ & 42.5 & 41.25 & 40.5 \\
\hline EDRY & M€ & 4 & 3 & 2 \\
\hline EFLUID & M€ & 1.9 & 1.5 & 1.15 \\
\hline EO\&M & M€ & 4.84 & 4.58 & 4.37 \\
\hline E $_{\text {TOT }}$ & M€ & 51.34 & 48.83 & 46.87 \\
\hline \multicolumn{5}{|c|}{ Solar Thermal 3 M€/MW } \\
\hline Enits & Scen. P & Scen. BE & Scen. O \\
\hline ESOLAR (FLUID+DECARB) & M€ & 51 & 49.5 & 48.6 \\
\hline EDRY & M€ & 4 & 3 & 2 \\
\hline EFLUID & M€ & 1.9 & 1.5 & 1.15 \\
\hline EO\&M & M€ & 5.69 & 5.4 & 5.18 \\
\hline ETOT & M€ & 60.69 & 57.9 & 55.78 \\
\hline Solar Thermal 3.5 M€/MW \\
\hline ESOLAR (FLUID+DECARB) & Units & Scen. P & Scen. BE & Scen. O \\
\hline EDRY & M€ & 59.5 & 57.75 & 56.7 \\
\hline EFLUID & M€ & 4 & 3 & 2 \\
\hline EO\&M & M€ & 6.54 & 1.5 & 1.15 \\
\hline ETOT & M€ & 70.04 & 6.23 & 5.98 \\
\hline
\end{tabular}


Table 12: Total Investment costs and yearly revenue for scenarios of analysis.

\begin{tabular}{c|c|c|c}
\hline TOTAL INVESTMENT & SCENARIO P & SCENARIO BE & SCENARIO O \\
\hline SOLAR THERMAL COST 2.5 M€/MW & $51.34 \mathrm{M} €$ & $48.83 \mathrm{M} €$ & $46.87 \mathrm{M} €$ \\
\hline SOLAR THERMAL COST 3 M€/MW & $60.69 \mathrm{M}$ & $57.90 \mathrm{M} €$ & $55.78 \mathrm{M} €$ \\
\hline SOLAR THERMAL COST 3.5 M€/MW & $70.04 \mathrm{M} €$ & $66.98 \mathrm{M} €$ & $64.69 \mathrm{M} €$ \\
\hline ANNUAL ECONOMIC PROFIT & $8.08 \mathrm{M} €$ & $11.58 \mathrm{M} €$ & $15.08 \mathrm{M} €$ \\
\hline
\end{tabular}

Table 13: $\mathrm{CO}_{2}$ emission data for different scenarios.

\begin{tabular}{c|c|c|c|c}
\hline & $\begin{array}{c}\text { REFERENCE } \\
\text { PLANT }\end{array}$ & $\begin{array}{c}\text { DRY } \\
\text { CARBONATE } \\
(\mathrm{P})\end{array}$ & $\begin{array}{c}\text { DRY } \\
\text { CARBONATE } \\
(\mathrm{BE})\end{array}$ & $\begin{array}{c}\text { DRY } \\
\text { CARBONATE } \\
\text { (O) }\end{array}$ \\
\hline Power (MWel) & 15 & 15 & 15 & 15 \\
\hline CCS Power consumption (MWel) & & 2.5 & 1.6 & 1.5 \\
\hline Regenerator Heat requirement (MWth) & & 11.9 & 11.4 & 11.1 \\
\hline Net power (MWel) & 15 & 12.5 & 13.35 & 13.5 \\
\hline $\mathrm{CO}_{2}$ Emissions (tons/hr) & 13.5 & 1.07 & 1.07 & 1.07 \\
\hline $\mathrm{CO}_{2}$ Emissions (kmol/hr) & 308 & 24.32 & 24.32 & 24.32 \\
\hline $\mathrm{CO}_{2}$ Avoided Emissions (kton/year) & & 108.9 & 108.9 & 108.9 \\
\hline $\mathrm{CO}_{2}$ Emissions (tons/ MWhel) & 0.9 & 0.085 & 0.08 & 0.079 \\
\hline
\end{tabular}

Table 14: Revenues due to $\mathrm{CO}_{2}$ emission reduction for different scenarios (20 years).

\begin{tabular}{c|c|c|c}
\hline & SCENARIO P & SCENARIO BE & SCENARIO O \\
\hline Carbon Tax & $10 € /$ ton $_{\text {CO2 }}$ & $18 € /$ ton $_{\text {CO2 }}$ & $25 € /$ ton $_{\text {co2 }}$ \\
\hline Yearly Economic Gain & $1.09 \mathrm{M} € /$ year & $1.96 \mathrm{M} € /$ year & $2.72 \mathrm{M} € /$ year \\
\hline $\mathrm{IR}=0.08$ & $10.89 \mathrm{M} €$ & $19.60 \mathrm{M} €$ & $29.00 \mathrm{M} €$ \\
\hline $\mathrm{IR}=0.1$ & $8.72 \mathrm{M} €$ & $15.70 \mathrm{M} €$ & $23.18 \mathrm{M} €$ \\
\hline $\mathrm{IR}=0.12$ & $7.71 \mathrm{M} €$ & $13.88 \mathrm{M} €$ & $20.33 \mathrm{M} €$ \\
\hline
\end{tabular}

10

12

Table 15:NPV(20 years) values including savings from $\mathrm{CO}_{2}$ emission reduction.

\begin{tabular}{c|c|c|c|c}
\hline IR & SOLAR COST(M€/MW) & SCENARIO P & SCENARIO BE & SCENARIO O \\
\hline \multirow{3}{*}{0,08} & 2.5 & 38.93 & 84.51 & 130.24 \\
\cline { 2 - 5 } & 3 & 29.58 & 75.44 & 121.33 \\
\cline { 2 - 5 } & 3.5 & 19.87 & 66.34 & 112.41 \\
\hline \multirow{3}{*}{0,1} & 2.5 & 26.22 & 65.50 & 104.73 \\
\cline { 2 - 5 } & 3 & 16.87 & 56.43 & 95.82 \\
\hline \multirow{3}{*}{0,12} & 3.5 & 7.6 & 47.33 & 86.90 \\
\cline { 2 - 5 } & 2.5 & 16.77 & 51.58 & 86.14 \\
\cline { 2 - 5 } & 3 & 7.42 & 42.51 & 77.23 \\
\hline
\end{tabular}

